\title{
The Effects of Market Liberalization on the Relative Earnings of Chinese Women
}

By: Margaret Maurer-Fazio and James Hughes

William Davidson Working Paper Number 460

March 2002 
The Effects of Market Liberalization on the Relative Earnings of Chinese Women

\author{
Margaret Maurer-Fazio \\ Department of Economics \\ Bates College \\ Lewiston, ME 04240 \\ (207) 786-6097 (phone) \\ (207) 786-8337 (fax) \\ mmaurer@bates.edu \\ and \\ James Hughes \\ Department of Economics \\ Bates College \\ Lewiston, ME 04240 \\ (207) 786-6193 (phone) \\ (207) 786-8337 (fax) \\ jhughes@bates.edu
}

Suggested Running Head: The Relative Earnings of Chinese Women

March 2002 
William Davidson Institute Working Paper 460

\title{
The Effects of Market Liberalization on the Relative Earnings of Chinese Women
}

\begin{abstract}
In this paper we first explore the effects of differences in labor market institutions and the degree of market liberalization on the size and composition of gender wages gaps in China's urban labor markets. We use enterprise-ownership type, enterprise age, and workers' methods of finding employment as proxies for the extent of market liberalization. We find both the size of the wage gaps and the proportion of the gap left unexplained by differences in productive characteristics largest in the most liberalized (joint venture) sector, and smallest in the least liberalized (state) sector. We next investigate the effects of differences in wage structure on the gender wage gaps. We find that differences in wage structure, in general, and the degree of wage dispersion, in particular, are extremely important in accounting for the larger wage gaps in the joint venture and collective sectors relative to the state-owned sector.
\end{abstract}

Journal of Economic Literature Classification: J16, J31, J71, O15, O53, P23

Keywords: China, gender wage gap, labor, market liberalization, earnings 


\section{William Davidson Institute Working Paper 460}

\section{Introduction $^{1}$}

At the macro-economic level, the Chinese economic reform program produced rapid and sustained growth and improvements in material welfare. In the period from the late 1970s to the early 1990s, per capita GDP more than quadrupled (ZTN 2000).

However, the benefits of reform were distributed unevenly. It is well known that income and welfare rose more quickly in the eastern seaboard provinces than in the western and interior ones (Chen and Fleisher 1996, Fleisher and Chen 1997, Gustafsson and Li 1998, Lee 2000 ). Less well known is the impact of the reforms on the differences between men's and women's earnings.

As Becker (1971) first pointed out, when workers can choose amongst employers, firms that discriminate and pay disfavored groups less than their marginal revenue product and favored groups more than their marginal revenue product will suffer a cost disadvantage. The cost disadvantage arises not only from overpaying favored groups but also from the displacement of higher skilled, discriminated against workers by less skilled but favored workers. All else equal, managers whose compensation is linked to the profitability of the firm are less likely to discriminate than those who are unaffected by the higher cost structure.

China's economic reforms increased managers' ability to discriminate by decentralizing wage setting to firms. At the same time, the reforms increased managers' stake in the cost effectiveness of the firm and bequeathed workers a new-found freedom

\footnotetext{
1 The authors are particularly indebted to Sarah Cook, Michael P. Murray, Thomas G. Rawski and the Journal's editor and referees for insightful comments on earlier drafts. We are also very grateful to Xin Meng for her generous help with the computer code for the Juhn decompositions.
} 
to change jobs and choose employers. If managers are generally more prone to discriminate than were the pre-reform centralized wage scales, then the reforms could set opposing forces in motion. The question thus arises as to whether the more liberalized sectors have larger or smaller gender pay gaps than less liberalized sectors. We investigate this question in the present study, using differences in institutional structure (enterprise ownership, age of the enterprise, and method of job-seeking) as proxies for the degree to which wage and employment decisions are influenced by market forces.

Khan, pondering the effects of a decade of reform on the condition of women in urban China, writes, "Women clearly shared in the benefits of reforms, although there is little solid evidence to determine if they benefited proportionately more or less than men did...” (Khan, 1996, Section VI). More recent works suggest increasing disparities between men's and women's incomes in China (Maurer-Fazio et al.1999, Li and Gustafsson 1999, Chen Gang et al. 1999, Rawski 2002).

Brainerd (1998) finds that wage inequality in Russia nearly doubled in the first two to three years of wage and price liberalization and that while women's mean earnings were 79.5 of men's in 1991 they fell to only 63.5 percent of men's by 1994 . In a comparison of the gender wage gaps among the transition economies of central and eastern European, Brainerd (1997) finds the gender wage gaps to be larger, in both absolute and relative terms, in Russia and the Ukraine, and smaller in Poland, Hungary, Slovenia, Bulgaria and the Czech and Slovak Republics. She argues that the crosscountry differences in the gender wage gaps are primarily due to differences in the degree of wage-setting decentralization and not due to differences in macroeconomic performance across countries. 
The positive association of decentralization in wage setting with increased gender wage gaps does not necessarily imply an increase in discrimination. Other authors have examined the importance of differences in wage structures across industries, firms, and nations in explaining gross wage gaps between skill, racial, or gender groups structure. ${ }^{2}$ For example, Blau and Kahn (1996) show that the persistently high (by international standards) gender wage gap in the United States is due in large part to a substantial and increasing level of overall wage inequality in the U.S. Bronars and Famulari (1997) find that 35 to 40 percent of between-firm wage differentials are due to differences in the wage structures of the firms with the remainder due to between-firm differences in employee characteristics. They also report that within-firm gender wage differentials are smaller than across-firm ones and that much of the male-female gap for less educated and less experienced workers is due to the crowding of women into low-paying firms. These results suggest that differences in wage structure can be an important source of gender wage differentials and should not be ignored when analyzing differences in gender wage gaps.

Although the cross-section nature of our data ${ }^{3}$ prohibits us from directly examining the changes in women's earnings relative to men's over the course of the reforms, we are able to use sectoral variation in the degree of market liberalization to

\footnotetext{
2 See, for example, Juhn, et al. (1991), Bronars and Famulari, (1997), and Abowd et al. (1999).

3 The data we employ in our empirical analysis was collected in 1992--a period well into the reform process.
} 
infer the affects of the reforms. ${ }^{4}$ We also exploit sectoral variation in wage dispersion to explore how much of the differences in the wage gaps is due to differences in wage structures. We focus on how institutional differences affect the relative incomes of working women and men in China's urban labor markets. We first measure the extent of gender wage differentials in a large, micro-level data set. Next, employing techniques developed by Blinder (1973), Oaxaca (1973), and Neumark (1988), we decompose the gross wage differentials into components attributable to differences in productive characteristics (education and work experience) and differences in labor-market treatment. We then explore how differences in the degree of market liberalization affect these components by employing measures of enterprise ownership, enterprise age, and workers' methods of finding employment as proxies for market liberalization. Finally, we use the techniques developed by Juhn et al. (1991) to ascertain the extent to which sectoral differences in wage dispersion contribute to the differences in gender wage gaps.

\section{Urban China's Changing Labor Market Institutions}

China's pre-reform labor system was the antithesis of a free market system. The state claimed ownership of labor services and bureaucratically assigned workers to enterprises for life. Workers' preferences concerning occupation or location mattered little. For the enterprises' part, managers had to accept any and all workers allocated to them. Enterprises could not recruit particularly well-qualified workers, nor could they

$4 \quad$ Liu et al (2000) employ a similar strategy and compute and decompose gender wage gaps for private sector and public sector firms in Shanghai and Jinan. They find the size of gap in wages left unexplained after taking into account differences in productive characteristics larger in the private sector than in the state sector. However, they find the share of this unexplained gap as a fraction of the total wage gap smaller in the private sector than in the state sector 
fire unproductive workers. The wage system was not designed to promote productivity and motivate workers but rather to provide egalitarian incomes. In this goal, the Chinese wage system enjoyed a modicum of success. Chinese workers, men and women, received nearly equal pay regardless of their efforts, productivity, or performance.

When reforms were initiated in the late-1970's, concerns about open unemployment and social instability caused the Chinese leadership to embark on a slow, evolutionary transition to a market economy. The demands for more flexible and efficient labor markets brought by a new generation of profit-motivated managers were initially resisted, experimented with, and introduced only gradually. Yet even these initial, tentative steps toward market rationalization rapidly yielded profound changes in China's labor system. Workers gained the freedom to choose where and for whom they would work. A vibrant private sector emerged in which managers had the right to determine the size and composition of their work force. Most importantly for the issues being investigated in this paper; there was a strong movement towards decentralized, productivity-determined remuneration. Wage variation across workers and sectors increased relative to the pre-reform period (Maurer-Fazio et al. 1999). Chinese workers experienced considerable change in their work environment.

\section{Women's Relative Status and Pay}

Chinese women's work experience, status, and pay are affected by a complex interplay of newly-introduced market forces, a legacy of centralized work place institutions, traditional beliefs that women are subordinate to men, and a socialist 
ideology of gender equality. Confucian thought and beliefs continue to exert influence on Chinese society ${ }^{5}$ and may contribute to gender discrimination in the work place.

Under socialism, the traditional low status of women in Chinese society was to become an artifact of the past. The Chinese constitution guaranteed women equal rights with men in all spheres of life and assured equal pay for equal work. ${ }^{6}$ In the first decades

5 Confucian doctrine takes a very hierarchical view of society. Key human relationships link superiors to subordinates with sons subordinate to fathers, subjects subordinate to rulers, and wives subordinate to husbands. In the first century C.E., the famous female historian and scholar, Ban Zhao, consolidated existing attitudes towards women into a set of prescriptive norms for women's lives, Nujie, (Precepts for Women). Ban Zhao unequivocally stated the position of women as lowly and weak and destined to serve others. The effects of her writing on attitudes about women's roles in society intensified in the Neo-Confucianism period. (Lee, 1994 pp. 4-24). Women's place and status were determined by these Confucian cosmological beliefs (Croll, 1995 p.12-13).

${ }^{6}$ Women were paid substantially less than men in China's pre-socialist society. Rawski (1989), in his argument about economic growth in prewar China, claims that China's largest prewar industry was cotton textiles and that Jiangsu Province was home to the largest concentration of textile mills. Many of the mills' employees were young women recruited from the surrounding rural areas. Rawski establishes the close relationship of rural wages to textile mills' wages. The occupational segregation by gender in the mills makes it difficult to sort out the effects of skill, experience and gender in explaining the differences in pay. However, Rawski presents data on annual wages paid to male and female farm workers in forty-four of Jiangsu's counties for the period between 1923 and 1932 in which women's earnings vary from 61 to 65 percent of men's. (Calculated from Table 6.7 (Rawski 1989, p.306)).

Arnold's 1926 Commercial and Industrial Handbook devotes 372 pages to reports on economic activities in China's consular districts. Most of these reports contain a section on labor conditions that yields information on wages. In the cases where it is possible to compare male and female wages, for similar but broadly defined occupations, the male wage premium varies from 0 to 400 percent.

There are also a number of historical accounts and case studies of particular industries and mills that give us anecdotal information on women's pay in pre-socialist China. For example, Honig (1986, pp.41-56) paints a very detailed picture of women's work lives in the Shanghai cotton mills in the first half of the $20^{\text {th }}$ Century. Women and men tended to do different jobs although the jobs considered women's work or men's work varied from mill to mill. Honig reports that the cotton mills responded to the depression in the 1930s by doing what they could to reduce expenses. There was a corresponding change in the division of labor as women were hired to do some of the tasks formerly done by men. Honig gives an example of the Shen Xin Number Nine Mill 
of the revolution, women's work was promoted with the slogan that women hold up half of heaven, a traditionally male realm (Croll, 1995. p.99). Work was symbolically important in both liberating and providing equality for women (Croll, 1995 p. 117).

Chinese women appear to have internalized the ideology and rhetoric that participation in paid labor would dramatically improved their status. Women exhibited a strong sense of entitlement to a good job (Loscocco and Bose, 1998 p.106). Female labor force participation on the eve of reform has been estimated at 90 percent. Women's labor force attachment was extremely strong (Croll, 1997. p.6). ${ }^{7}$

Despite the rhetoric of equality, in rural areas gender wage differentials persisted. Accounts of urban young people sent to rural areas make clear that women on the communes were paid less than men even when carrying out the same tasks (Chan et al. pp.92-93, Zhai pp.170-171). However, the centrally-administered wage grade system in effect in urban areas made such overt discrimination less likely. On the eve of the reforms, China's urban gender wage gap was small in international perspective. ${ }^{8}$

where women spinners' wages fell from 0.432 yuan per day in 1931 to 0.327 per day in 1935 while at the same time, the wages of male packers rose from 0.557 to 0.689 yuan per day.

$7 \quad$ Contrast the labor force participation of Chinese women with that of their U.S. counterparts. As recently as 1970, women's labor force participation in the U.S. stood at 48 percent for white women, and 59 percent for black women. Even by 1995, the labor force participation rate had risen to 72 percent for white women and 70 percent for black women. Only American women with at least some postgraduate education had participation rates approaching or exceeding the 90 percent witnessed in China (Blau, Ferber, and Winkler, page 117, Table 4.5.).

$8 \quad$ Meng and Kidd (p.9) report, based on a large sample of workers in state-owned enterprises, that in 1981 (the eve of reforms in industry) women earned 14 percent less than men on average. 
With the advent of economic reform, wage plans were decentralized to local authorities, allowing employers to diverge from national wage scales. Coverage of the wage grade system narrowed, as private sector as well as township and village enterprises were exempted from it. Bonuses, paid out of retained earnings, became an important component of workers' total monetary compensation. Workers' earnings became linked to their own productivity and managers' compensation to the profitability of their enterprises. The decentralization of remuneration decisions allowed managers much more leeway in rewarding productivity.

The reduction in government involvement in the labor market meant that managers had more freedom to engage in discriminatory practices. Thus, the subordination of and discrimination against women in Chinese society could reemerge, reducing women's share of the gains to economic reform. Meng (2000) argues that this did not occur. She contends that the programs promoting gender equality in China during the socialist period were effective in changing social attitudes towards women, as evidenced by wage gaps up to 1995 that remained small in both international perspective and in comparison to wage gaps in Taiwan, an area sharing a common cultural heritage.

In contrast to Meng, Maurer-Fazio et al.(1999) and Li and Gustafsson (1999) report wage gaps for urban workers in China that increase over the periods of their respective studies. Both of these papers suggest that wage gaps are largest in the sectors having the most market influence. There is no doubt that over the course of the reforms managers gained a much greater stake in the profitability of their enterprises. This implies, ceteris paribus, less likelihood of engaging in costly discrimination. Does the increase in size of the wage gap thus imply that managers are increasingly engaging their 
tastes for discrimination? Obviously there are other factors in play in the complex and changing milieu of the urban work place in China.

There is little doubt that the Chinese labor market has become more varied, with some firms clinging to the employment practices of the socialist period, while others hire, fire and compensate workers in response to market forces and the desire to maximize profit. With such diversity in the labor market, it is possible that systematic differences in wage structure may have emerged that could affect the size of the wage gap.

Differences in the wage structure across different types of Chinese firms could influence the relative size of the wage gap in the two sets of firms. Suppose, for example, women have less education on average compared to men, and that the difference is the same between state-owned and joint venture enterprises. If the return to education were higher in joint venture firms than in state-owned firms, we would observe a larger gender wage gap in the joint venture firms. Thus, competition for educated workers by joint venture firms could lead to larger gender wage gaps, ceteris paribus.

\section{Research Strategy}

As indicated above, if the state was effectively protecting women from discriminatory remuneration schemes in the pre-reform period it is quite possible that in the reform period we observe increased discrimination against women in the more competitive and less controlled sectors of the labor market. We examine this issue by dividing our cross-sectional data along three dimensions, each associated with varying degrees of market liberalization and then employing the Oaxaca (1973)/Blinder (1973) and Neumark (1988) decomposition methods described below to analyze differences in the size and composition of the resulting gender wage differentials. 


\section{William Davidson Institute Working Paper 460}

First, we examine how the relative wages of men and women vary across three types of firm ownership: state, collective, and joint venture. In the state-owned sector ultimate control rests with agencies of the national government. Collective enterprises are owned by local communities or local governments. The joint venture enterprises are those involving offshore investors.

State-owned enterprises, while changing rapidly in recent years, maintained many restrictive employment practices during our survey year. We expect the spread of market forces to least affect the state-owned enterprises where restrictions on hiring, dismissals, transfers, and pay were much more severe than for collectives or joint ventures. We expect that the joint venture enterprises generally function in more competitive labor markets and have the most flexible wage payment schemes. The need to generate profit for the private sector partner should also reduce the ability of joint venture firms to engage in costly discriminatory practices.

China's course of reform was gradual, partial, and unevenly implemented. Yet by the mid-1980s, two significant sets of enterprise reforms were in place. The first allowed firms to retain a share of their profits and the second allowed managers to exchange commodities produced outside the plan in markets (Rawski,1994). In late 1984 the Communist Party Central Committee promulgated the idea that workers' effort and productivity be closely linked with material reward (Child, 1994 p.186).

The new profit motivation and the possibility of tying reward to effort began to affect managers' resource allocation decisions, in particular their labor allocation decisions. However, given the established agent/client relationships of the pre-reform period, the persistence of learned behavior, and the gradual and uneven implementation 


\section{William Davidson Institute Working Paper 460}

of reform policies, we posit that newer firms were more much more likely to face harder budget constraints than older firms, regardless of ownership. In addition, enterprises formed after the initiation of reforms (again, regardless of ownership) were likely to be relatively free of the legacy of egalitarian wage policies. We posit that newly created firms were more susceptible to competitive pressures than their pre-reform counterparts.

To examine the effect of these possibilities on the relative wages of women, we simultaneously divide the sample by age of enterprise and enterprise ownership. We classify firms created in 1984 and before as "old" and those firms created in 1985 or after as "new." We chose 1984 as the pivotal year for three reasons. First, the initial tranches of industrial reform measures were in effect by that date (Jefferson and Rawski, 1994). Second, the Party promulgated the policy of linking effort and reward in that year. Third, a change in regulations that year permitted enterprises to engage in open recruitment practices (Child, 1994, p.271)

Another important change in Chinese labor markets is the increasing use of competitive channels, rather than state labor bureaus, by firms wishing to fill vacancies and by employees seeking new positions. Competitive job seekers participated either in open competitive exams, or obtained their jobs through employment agency referrals. Labor bureaus assigned workers to their employers upon completion of their schooling or demobilization from the armed services. In addition, many workers obtained their jobs by being recommended by their friends or relatives, by replacing their parents within an enterprise, or by being transferred. We expect that when jobs are obtained competitively, as is increasingly common, the relative abilities of employees, rather than personal tastes or relationships, dominate the employment decision. We thus divide our sample 
accordingly and compare the effects of competitive job search to job assignment on the size and composition of the gender wage gap.

Finally, we examine the influence of wage structure and gender, the relative size of wage gaps in state enterprises and both collective and joint ventures using the methodology developed by Juhn, et al. (1991). This method allows us to evaluate the contribution of qualifications; measured prices, relative gender inequality between ownership types, as well as inter industry differences in overall residual inequality between men and women.

\section{Decomposing the Gender Wage Gap}

We first use the well-known procedure developed by Oaxaca (1973) and Blinder (1973) to analyze the composition of the gender wage gap. This procedure splits the total gender wage differential into two components: that part of the differential attributable to gender differences in observable productive characteristics (e.g., education), and the residual gap attributable to differences in the male and female returns to these productive characteristics. This residual, or unexplained, component of the wage gap is generally attributed to discrimination, but could be also due to differences in unobserved productive characteristics.

More formally, the total gender wage gap is equal to

$$
\ln \hat{W}_{M}-\ln \hat{W}_{F}=\bar{X}_{M} \hat{\mathrm{B}}_{M}-\bar{X}_{F} \hat{\mathrm{B}}_{F}
$$

where $\ln \hat{W}_{M}$ and $\ln \hat{W}_{F}$ are the estimates of the natural log of male and female wages, respectively, from separate wage regressions by sex. $\bar{X}_{M}$ and $\bar{X}_{F}$ are vectors of the mean values of the male and female productive characteristics, and $\hat{\mathrm{B}}_{M}$ and $\hat{\mathrm{B}}_{F}$ are 


\section{William Davidson Institute Working Paper 460}

vectors of the estimated regression coefficients from the male and female wage regressions.

This gross wage differential may be decomposed by rearranging the above expression as follows,

$$
\ln \hat{W}_{M}-\ln \hat{W}_{F}=\left(\bar{X}_{M}-\bar{X}_{F}\right) \hat{\mathrm{B}}_{M}+\bar{X}_{F}\left(\hat{\mathrm{B}}_{M}-\hat{\mathrm{B}}_{F}\right)
$$

The first expression on the right hand side is that portion of the wage differential attributable to differences in the average productive and other characteristics of men and women. The difference in the mean characteristics is multiplied by the estimated coefficients from the men's regression. These coefficients are interpreted as the men's wage structure, or the men's return to these productive characteristics. The second expression on the right is that portion of the wage differential attributable to differences in the male in female regression coefficients - i.e., differences in the returns to men and women for the same productive characteristics. It is this latter component that is generally attrib uted to discrimination.

A difficulty with this decomposition is that it values the difference in male and female productive characteristics according to the male returns, $\hat{\mathrm{B}}_{M}$. Performing the decomposition in this way assumes that the male wage structure is the wage structure that would prevail absent discrimination. The gross wage differential could also be decomposed as follows, with equal validity

$$
\ln \hat{W}_{M}-\ln \hat{W}_{F}=\left(\bar{X}_{M}-\bar{X}_{F}\right) \hat{\mathrm{B}}_{F}+\bar{X}_{M}\left(\hat{\mathrm{B}}_{M}-\hat{\mathrm{B}}_{F}\right)
$$

In this expression, the difference in the mean productive characteristics between men and women are valued according to the female return. This decomposition assumes that the female wage structure would prevail in the absence of discrimination. While functionally 
equivalent, these two decompositions in practice generally yield different estimates for the wage differential components.

Neumark (1988) proposes an alternative decomposition in which the wage structure that would obtain in the absence of discrimination lies in between the current male and female wage structures. He proposes that the nondiscriminatory wage structure could be estimated using the regression coefficients from a pooled male-female salary regression. In this way, the gross wage differential could be broken down into three components - the portion attributable to differences in productive characteristics, a portion showing the wage advantage accruing to men (i.e., the amount that men are paid, on average, in excess of the nondiscriminatory wage structure), and the women's wage disadvantage (i.e., the amount by which women are underpaid, on average, relative to the nondiscriminatory wage structure). This decomposition may be written as

$$
\ln \hat{W}_{M}-\ln \hat{W}_{F}=\left(\bar{X}_{M}-\bar{X}_{F}\right) \hat{\mathrm{B}}_{P}+\bar{X}_{M}\left(\hat{\mathrm{B}}_{M}-\hat{\mathrm{B}}_{P}\right)+\bar{X}_{F}\left(\hat{\mathrm{B}}_{F}-\hat{\mathrm{B}}_{P}\right)
$$

where $\hat{\mathrm{B}}_{P}$ is the estimated nondiscriminatory wage structure, derived from a pooled regression of men and women.

In our analysis, we present decompositions of the gender wage gap calculated using the Oaxaca/Blinder method, assuming that the male wage structure would be the nondiscriminatory wage structure. We believe that this assumption is likely to hold in Chinese labor markets. As a check, we also present decompositions calculated using the Neumark method assuming a pooled wage structure as the nondiscriminatory wage structure. 
The Juhn, et al. (1991) procedure allows us to examine the source of differences in the gender wage gaps between different types of firms. Following Blau and Kahn (1996), a gender wage gap equation for state-owned firms may be written as:

$$
\begin{aligned}
& \qquad D^{S} \equiv \ln \hat{W}_{M}^{S}-\ln \hat{W}_{F}^{S}=\left(\bar{X}_{M}^{S s}-\bar{X}_{F}^{S}\right) \hat{B}_{M}^{S}+\bar{X}_{F}^{S}\left(\hat{B}_{M}^{S}-\hat{B}_{F}^{S}\right) \\
& \text { or } \quad D^{S}=\Delta X^{S} B_{M}^{S}+\sigma^{S} \Delta \theta^{S} \\
& \text { where } \\
& \Delta X^{S}=\left(\bar{X}_{M}^{S}-\bar{X}_{F}^{S}\right) ; \\
& \sigma^{S} \Delta \theta^{S}=X_{F}^{S}\left(\hat{B}_{M}^{S}-\hat{B}_{F}^{S}\right) ; \\
& \sigma^{S}=\text { residual standard deviation of male wages in state enterprises; } \\
& \theta^{S}=\text { standardized residual (mean 0, variance 1); }
\end{aligned}
$$

The difference in the gender wage gap between, for example, state enterprises and joint ventures may be decomposed as follows:

$$
\begin{aligned}
D^{J}-D^{S}= & \left(\Delta \bar{X}^{J}-\Delta \bar{X}^{S}\right) B^{S}+\Delta \bar{X}^{J}\left(B^{J}-B^{S}\right)+ \\
& \left(\Delta \theta^{J}-\Delta \theta^{S}\right) \sigma^{S}+\Delta \theta^{J}\left(\sigma^{J}-\sigma^{S}\right) .
\end{aligned}
$$

The first term in (6) captures the contribution of differences in human capital and other observed characteristics to the difference in gender wage gap between the two ownership types. The second term reflects differences in the price paid in the two types of firms for a given set of qualifications.

The third term represents the contribution of the residual difference in the relative standing of men and women after controlling for observed human capital characteristics. This term captures differences in the gender wage gap attributable to differences in women's relative standing in the male residual wage distribution in state enterprises and 


\section{William Davidson Institute Working Paper 460}

joint ventures. Following Blau and Kahn's terminology, we label this term the 'gap' effect.

The fourth term in (6) measures inter-industry differences in overall wage inequality after controlling for measured characteristics. The more unequal are mean wages of men between state enterprises and joint ventures, the larger will be women's wage penalty due to discrimination or differential returns to unmeasured characteristics. Again following Blau and Kahn's (1996) terminology, we refer to this effect as 'unobserved prices'.

\section{Data}

The data set used here was gathered in 1992 for use in the Chinese Labor Market Research Project (CLMRP), a joint project of the Economics Institute of the Chinese Academy of Social Sciences and the Labor Science Research Institute of the Ministry of Labor. Surveys were collected from 9397 individuals working in 430 different commercial and industrial enterprises under different forms of ownership located in 26 cities in 12 provinces. In each city the local labor bureau was asked to randomly select 20 to 25 enterprises from a list of all those under its jurisdiction with more than fifty employees. Once an enterprise was included in the sample a worker survey was administered to randomly selected employees. The employee questionnaire dealt with demographic characteristics, employment history, wages and compensation, on-the-job training, mobility and migration, working conditions, time allocation, and relationships between workers and their enterprises. The sample used here consists of all state, collective, and joint venture employees with reported income in 1991 and no missing values in critical variables: a total of 3453 males and 2697 females. 


\section{William Davidson Institute Working Paper 460}

The workers are relatively young and well educated. The mean age of male and female employees is 36 and 32.5 years, respectively. Educational attainments of men and women differ little: males have a mean of 11.4 years of schooling and females 11.3 years. At the top end of the educational scale, 8 percent of males and 4 percent of females report university graduation. ${ }^{9}$ The men in this sample work 47.5 hours per week and earn 198 yuan per month on average while the women work an average of 47.1 hours per week and earn 170 yuan per month. The majority of workers have long-term attachments to their enterprises: only 21 and 28 percent of male and female workers, respectively are contract and temporary workers. (See Appendix Table A1 for sample means and proportions of key variables by enterprise ownership.)

Only 48 percent of the males and 39 percent of the females work in state-owned enterprises; 32 percent of males and 39 percent of females work in collectively-owned enterprises; and 20 percent of males and 22 percent of females work in privately-owned or joint venture enterprises. These figures are not reflective of the labor force, ${ }^{10}$ but rather of the survey design which attempted to select adequately sized samples of state-owned, collectively-owned, and joint venture enterprises in each city. ${ }^{11}$

$9 \quad$ These proportions may seem surprisingly high given that only 0.65 percent of the population were university graduates in 1987. However the national figure masks marked differences in the distribution of educational attainments between rural and urban areas. The sample used here is drawn only from the working population in urban areas.

10 In 1991, 62.8 percent of employed persons in urban areas were employed by state-owned enterprises, 21.3 percent were employed by collective enterprises, and the remaining 15.9 percent were employed under other forms of ownership, including joint venture, foreign-funded, private and individual ownership. (ZTN 1997, Table 4-4, pp. 967)

11 Differences in the sample and population proportions of workers in state, collective, and joint venture workers do not present a problem in analyzing the gender wage gap here since we compare results by ownership sector. 


\section{William Davidson Institute Working Paper 460}

Enterprise surveys were also administered to each firm in the sample. Of the 422 firms in the enterprise survey that reported ownership, 173 were classified as stateowned, 145 as collectively-owned and 99 as joint ventures. Firms declared as joint ventures had both Chinese and foreign partners. Of the 83 joint-ventures where the source of Chinese capital is reported, 6 were funded by centrally-administered enterprises, 14 by provincially-administered enterprises, 47 by municipally-administered enterprises, and 16 by "other" types of firms. The first source of foreign funding for the 92 joint ventures reporting this information was Hong Kong for 56 enterprises, Taiwan for 12 enterprises, Japan for 7 enterprises, Macau for 2 enterprises, Canada for 2 enterprises, the United States for 2 enterprises, and South Korea for 1 enterprise, and "other" for 11 enterprises.

The firms in the enterprise sample together employed over 467,000 people.

Women made up 39 percent of the total number of employees. The percentage of women employees varied quite dramatically by ownership. Women constituted 35 percent of the labor force of state-owned firms, 45 percent of the collectively-owned firms and 51 percent of the joint-venture firms. ${ }^{12}$

The data in the enterprise survey reveal that half the firms began operation before 1969 and half on or after that year. We have, however, for reasons discussed above, chosen 1984 as a pivotal year for classifying firms as old or new. According to this scheme, employees worked at 242 older firms, that is, those that began operation before 1985 and 88 newer firms, that is, those that started operation in or after 1985.

12 Maurer-Fazio et al. (1999) report that of the 148 million regular urban workers in China in 1992 that women constituted 34 percent of the labor force in state-owned firms, 39 percent in collectively-owned firms, and 50 percent in "other" firms. 
Table 1 reports several measures of our data's income dispersion by ownership sector and gender: the coefficient of variation of the natural log of monthly income, the difference in log income of the workers at the $90^{\text {th }}$ and $10^{\text {th }}$ percentiles of the distribution and the differences in log income of the workers at the $50^{\text {th }}$ and $10^{\text {th }}$ percentiles and those at the $90^{\text {th }}$ and $10^{\text {th }}$ percentiles. This table makes clear that income is much more dispersed in the joint venture sector than either of the other sectors.

Table 1

Income Dispersion by Ownership and Gender

\begin{tabular}{|c|c|c|c|c|c|c|c|}
\hline Ownership Sector & coefficient of & 90th & 50th & 10th & Difference & Difference & Difference \\
\hline & variation & Percentile & Percentile & Percentile & 90th-10th & 50th-10th & 90th-50th \\
\hline \multicolumn{8}{|l|}{ State Enterprises } \\
\hline Ln Men's Income & 7.930 & 5.733 & 5.273 & 4.787 & 0.946 & 0.486 & 0.460 \\
\hline Ln Women's Income & 7.600 & 5.620 & 5.136 & 4.719 & 0.901 & 0.417 & 0.484 \\
\hline \multicolumn{8}{|l|}{ Collective Enterprises } \\
\hline Ln Men's Income & 8.280 & 5.694 & 5.199 & 4.736 & 0.958 & 0.463 & 0.495 \\
\hline Ln Women's Income & 7.880 & 5.495 & 5.024 & 4.625 & 0.870 & 0.399 & 0.471 \\
\hline \multicolumn{8}{|l|}{ Joint Enterprises } \\
\hline Ln Men's Income & 9.930 & 6.215 & 5.521 & 4.868 & 1.347 & 0.653 & 0.694 \\
\hline Ln Women's Income & 10.400 & 5.991 & 5.298 & 4.727 & 1.264 & 0.571 & 0.693 \\
\hline
\end{tabular}

\section{The Wage Equations}

We estimate the following wage equation for each of our subgroups,

$$
\ln (w)=\alpha+\beta E D+\gamma X+\delta H O M E+\varepsilon,
$$

where the variables are described below.

We employ the natural log of total monthly income $\ln (w)$ as the dependent variable in the wage equations we use for decomposing the gender wage gap. Monthly income includes reported wages, bonuses, work subsidies, and income in kind. The value 


\section{William Davidson Institute Working Paper 460}

of medical care, pension accruals, and employer-provided housing is not included in the survey's measure of income.

The independent variables include a series of dummy variables that reflect educational attainment, $E D$, a vector $X$ of other personal and job-related characteristics including, classification of a worker wage grade system (cadre, worker, or ungraded), wage payment type (hourly, piece rate, fixed wage, floating wage), party membership, industrial classification, and provincial location. ${ }^{13}$ Measures of both total work experience and tenure at the current employer and their squared values are also included.

We also include measures of family size and number of children under 15 years of age, HOME. We realize that it is more typical to use family variables when estimating labor force participation rather than earnings but we speculate that the effect of these variables on women's labor supply may be of a somewhat different nature in China than in Western countries. In the West, the presence of children, especially young children, primarily affects women's labor force participation and attachment. However, as noted above, in China, women's labor force participation and attachment are particularly high. We think the great variation in child care arrangements plus the large role played by women in home production may cause some women to be unable or unwilling to take certain types of jobs, or to extend their job search beyond their city of residence. We include the child and family variables to control for the possible effects of these restrictions and choices on earnings.

13 The base case consists of middle-school educated, hourly-paid, "workers" who are employed in the food industry in Jiangsu Province and are not Party members. 


\section{William Davidson Institute Working Paper 460}

The regression results for these wage equations are reported by ownership and gender in the Appendix in Table A2. The explanatory power of these regressions is quite good: the adjusted $\mathrm{R}^{2}$ varies from a low of 0.384 in the regression for women in the collective sector to a high of 0.544 for women in the joint venture sector.

Earnings vary considerably by province relative to Jiangsu, our base case.

Workers in the highly developed southern coastal province of Guangdong earn premiums that vary between a low of 49 percent for male workers in the state sector and a high of 123 percent for male workers in the joint venture sector. Workers living in the poorer, interior province of Henan suffer wage disadvantages that vary from a low of 20.2 percent to a high of 44.2 percent, for males and females respectively, in the joint-venture sector.

In the state sector, each additional year of work experience, holding constant tenure with the current employer, increases monthly income by 3.3 and 2.6 percent for men and women, respectively. In the collective sector, the return to an additional year of schooling does not vary by gender and is constant at 2.3 percent. In the joint venture sector there is a wide discrepancy in the returns to experience-men earn an additional 4.8 percent for each incremental year of work experience while the return for women is 0 . Women, however, receive a positive reward for each incremental year of tenure with their current employer of 2.3 percent while men are penalized by 1.6 percent for each additional year with their current employer (holding total work experience constant).

In the joint venture sector, few of the education dummies have significant coefficients - university education being a notable exception. While educational attainment seems to have little effect on earnings in the joint venture sector, the picture is 
quite different for women in the collective sector where each level of education above the base case, junior middle school, receives a positive and significant return.

Party membership has a positive significant effect on earnings for only one group-men in the state sector. The family variables are for the most part insignificant, with one exception--a small negative effect of family size on women's earnings in the collective sector. Interestingly, being paid by piece rate (rather than on an hourly basis) significantly raises the earnings of men in all ownership sectors but does not affect women's earnings. Being on the cadre wage system raises the wages of all collective sector workers and women in the state sector but has no effect on the earnings of joint venture workers or state-sector males. In the joint venture sector, workers who are ungraded receive significantly higher earnings than graded workers while ungraded women in the state sector suffer significantly lower earnings.

\section{Decomposition Results}

\section{A. Enterprise Ownership}

We begin by using enterprise ownership as a proxy for liberalization. As described above, state-owned enterprises are relatively restricted in their hiring and dismissals. They are affected by a legacy of egalitarian wage policies stemming from a period of 'soft' budget constraints, in which profitability was not a managerial priority. The joint- venture firms face 'harder' budget constraints due to the need to generate profits for their off-shore investors. We speculate that the collective firms are intermediate cases since their budget constraints are clearly firmer than those in the statesector. These firms, however, may be less-profit driven than their joint-venture 
counterparts. The local community and/or local governments "owners" may impose goals such as employment creation over profit seeking.

We first examine how the relative wages of men and women vary with three types of firm ownership: state enterprise, collective enterprise, and joint ventures. As revealed in Table 2 below, the ordering of average wages is consistent over ownership type and gender, with joint venture enterprises paying the most and collectives the least.

The results of the wage decompositions, also shown in Table 2, reveal that of the three ownership types, state-owned enterprises have the smallest male-female wage differentials. Not only so, but the state-owned enterprises also have the smallest unexplained wage differential by both the Oaxaca and Neumark procedures.

\section{Table 2}

\section{Oaxaca and Neumark Decompositions by Enterprise Ownership ${ }^{1}$}

\begin{tabular}{lccc}
\hline & State Enterprise & Collective Enterprise & Joint Enterprise \\
\hline Wage & & \\
Average Male Wage & 190.62 & 181.91 & 248.38 \\
Average Female Wage & 170.35 & 154.35 & 198.07 \\
Wage Ratio (W/M) & 0.893 & 0.848 & 0.797 \\
N Male (Female) & $1,697(1,076)$ & $1,123(1,048)$ & $633(573)$ \\
Percent Unexplained & & & \\
Wage Differential & & & \\
Oaxaca $^{2}$ & 22.96 & 40.82 & 47.35 \\
Neumark & 20.99 & 43.23 & 47.45 \\
\hline
\end{tabular}

${ }^{1}$ Estimates calculated from regressions controlling for educational level, job-contract category, industry type, type of wage, family size, party membership, job tenure, experience, and province.

${ }^{2}$ The Oaxaca decompositions were performed using the male wage structure as the reference, or 'no-discrimination' wage structure.

Given these results, it appears that the proliferation of collective and joint venture enterprises over the course of the reforms is unlikely to have improved the relative 


\section{William Davidson Institute Working Paper 460}

economic position of female workers: the male-female wage differential is largest in the most liberalized sector, which also has the largest fraction of the wage gap unexplained by human capital or job characteristics. However, as noted above, differences in the dispersion of wages by ownership sector could imply that women's wages are a lower fraction of men's wages in a particular sector even when the gap in wages is itself constant across sectors. Interestingly, despite the fact that the gender wage differential is largest in the joint-venture sector, women's relative standing, as measured by where the median woman's income falls on the men's income distribution, is the highest in the this sector. The median woman's income falls at the 38.6 percentile of men's income in the joint venture sector, at the 32.3 percentile in the collective sector and at the 35.7 percentile in the state-owned sector. The large gender wage gap and unexplained residual in the most competitive sector is offset by the improvement in women's standing thus measured.

Despite the mixed picture of the relative position of women's pay in joint venture enterprises, their pay is unarguably higher than that of women working in the other two ownership sectors. Women in joint venture enterprises earn an average of 16 percent more than their state enterprise counterparts and 28 percent more than female workers in collective enterprises. Women in joint ventures earn slightly more on average than men employed in state enterprises. As mentioned above, the percentage of women employees by ownership varies markedly. In our sample, women constituted 35 percent of the labor force of state-owned firms, 45 percent of the collectively-owned firms and 51 percent of 
the joint-venture firms. Women thus make up a relatively large share of the labor force where their wages are highest. ${ }^{14}$

Maurer-Fazio et al. (1999) attribute much of the gender wage gap in China's urban labor markets to industrial segregation, that is, the crowding of women into lowpaying industries. If women are crowded into low-paying industries by discriminatory labor bureaus then our underlying regressions, which control for industry, may be "explaining away" part of the problem that we wish to examine. When we re-estimate our model excluding the dummy variables that control for industrial sector we find that the percentage of the wage gap that remains unexplained by differences in productive characteristics grows. In the state-owned sector, according to the Neumark method, the unexplained proportion of the wage differential increases from 21 percent to 30 percent. In the collective sector the unexplained portion grows from 43 to 49 percent and in the joint venture sector it grows from 47 to 50 percent. These results imply that women are subject to industrial segregation. The sector we thought to most "protect" women, the state sector, has the largest percentage point increase in the unexplained gap when the industry controls are omitted from the regressions. However, given that the earnings gap (measured in yuan per month) is smallest in this sector, the net effect of industrial segregation on monthly earnings is not necessarily larger here than in the other sectors. ${ }^{15}$.

14 The wages of male employees in joint venture enterprises exceed the wages of men in the other sectors to an even greater extent than do women's wages. The average male employee in a joint enterprise earns 30 percent more than a male state enterprise employee and 38 percent more than a comparable collective enterprise worker.

15 When we eliminate all variables from the underlying wage regressions except for a constant term, location dummies, education dummies, years of work experience and firm tenure (and their squared values) the unexplained portion of the wage differential rises to 33 percent in the state-owned sector and to 51 percent in the collective sector and 
Even after removing industry controls, the proportion of the wage gap explained by differences in human capital and other characteristics remains highest in the state sector. ${ }^{16}$

\section{B. Age of the Enterprise}

The distinction between various ownership types may be sharpened if we further divide the sample according to the age of the enterprise. Enterprises of all types formed during the post-reform period were founded in a more competitive atmosphere. By virtue of not having a long-standing agent/client relationship with government authorities, we believe that it is likely that the newer firms are better positioned to take advantage of the liberalization of the labor and product markets. In addition, this reduced relationship with the government also means that firms formed in the post-reform period likely face 'harder' budget constraints that limit managers' ability to engage in costly discrimination. Firms founded after the implementation of reforms are also free of most, if not all, vestiges of the earlier legacy of egalitarian wages and thus operate in a more competitive environment than older enterprises.

to 52 percent in the joint venture sector. The wage regressions for this "parsimonious" model are reported in the Appendix in Table A3.

16 Zveglich, Rodgers, and Roders (1997) analyze changes in gender earnings gaps in Taiwan's relatively unfettered labor markets. Taiwan shares a common cultural heritage but differs substantially in terms of institutional setting; comparisons are thus revealing. They find that the mean ratio of women's to men's wages stayed constant throughout the 1978-1992 period at 65 percent, that is a level substantially below any subset of our data. Over the period women improved their mean levels of education and work experience relative to men. They demonstrated no decline in their commitment to the labor force. Yet the unexplained component of the gender-pay gap increased over time (from 37.4 to 57.7 percent of the total gap). Zveglich et al. thus suggest that in Taiwan's relatively competitive labor environment discrimination against women increased over this period. 
Of course, the decentralization of control over remuneration also means that individual managers can indulge their tastes for discrimination. If the effects of profit motivation outweigh the effects of the new-found freedom to discriminate then we expect to see women faring better in new enterprises of all types than in older ones. The results from the analysis by enterprise age may be seen in Table 3.

Table 3

\section{Oaxaca and Neumark Decompositions by Enterprise Ownership and the Age of the Enterprise ${ }^{1}$}

\begin{tabular}{|c|c|c|c|c|c|c|}
\hline & \multicolumn{2}{|c|}{ State Enterprise } & \multicolumn{2}{|c|}{ Collective Enterprise } & \multicolumn{2}{|c|}{ Joint Enterprise } \\
\hline & Old & New & Old & New & Old & New \\
\hline \multicolumn{7}{|l|}{ Wage } \\
\hline Average Male Wage & 190.04 & \multirow{8}{*}{ 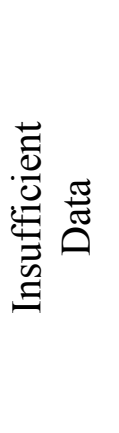 } & 184.64 & 156.75 & 223.48 & 262.49 \\
\hline Average Female Wage & 169.67 & & 156.85 & 134.77 & 183.05 & 207.50 \\
\hline Wage Ratio (W/M) & 0.893 & & 0.849 & 0.859 & 0.819 & 0.791 \\
\hline N Male & 1,625 & & 1,019 & 104 & 217 & 416 \\
\hline N Female & 1,040 & & 936 & 112 & 213 & 360 \\
\hline $\begin{array}{l}\text { Percent Unexplained } \\
\text { Wage Differential }\end{array}$ & & & & & & \\
\hline Oaxaca $^{2}$ & 27.73 & & 38.31 & 44.45 & 34.36 & 37.75 \\
\hline Neumark & 27.28 & & 47.17 & 42.52 & 34.97 & 38.84 \\
\hline
\end{tabular}

${ }^{1}$ Estimates calculated from regressions controlling for educational level, job-contract category, industry type, type of wage, family size, party membership, job tenure, experience, and province.

${ }^{2}$ The Oaxaca decompositions were performed using the male wage structure as the reference, or 'no-discrimination' wage structure.

The evidence shown in Table 3 is mixed. Looking first at older enterprises, as earlier, the female-male wage gap is smallest at state firms, and largest at joint venture enterprises. However, in a change of ordering from the above analysis based on all firms regardle ss of age, the fraction of the wage gap unexplained by differences in human capital characteristics is largest at collective enterprises, second largest at the joint venture enterprises and smallest in the state sector. 
How do women fare in newer enterprises? Unfortunately, the sample size for new state-owned enterprises (9 firms and 107 employees) was too small to analyze. In new collective enterprises, both male and female workers have lower mean wages in comparison to their colleagues in the older collectives. Measured in yuan per month, the female-male wage gap is lower in the new collectives but the ratio of women's to men's wages is almost identical. The fraction of the wage gap unexplained by human capital differences is higher in the newer collectives according to the Oaxaca measure, but lower according to the Neumark measure. While the absolute pay of both men and women is lower in the new collectives than in the older enterprises, our results do not yield a definitive answer as to whether women's relative situation improves or worsens.

Table 3 shows that women at new joint venture enterprises experienced slightly lower relative wages than their counterparts at older joint venture enterprises. Both the female-male wage gap and the unexplained portion of the gap are higher at new joint venture enterprises. However, the absolute wages of both men and women are higher at new joint venture enterprises compared with older joint venture enterprises. While newer joint venture enterprises, arguably the firms participating in the most liberalized labor markets, pay higher mean wages for women than the older firms, these women's mean earnings relative to men's have declined, as male wages have increased even more.

\section{Job Search Channel}

During the socialist period, workers were generally assigned to jobs. Workers could not refuse assignments, nor could enterprises refuse to accept new employees. Many of the respondents in our survey obtained their jobs in this way, while others found employment by competitive processes. If, on the one hand, the job assignment process 
incorporated the socialist egalitarian ethic and protected women from traditional discriminatory practices, then its removal could allow the reemergence of such practices and the crowding of women into low paying positions and sectors. On the other hand, as the above sections suggests, the job assignment system previously crowded women into low paying industries then competition for jobs could allow women to be judged on qualifications. Thus, escape from socialist control in job assignments could either hurt or help women.

We classified workers' job attainment method as 'competitive' if they participated in open competitive exams or were referred by an employment agency and as 'assigned' if they were assigned to the enterprise by a government bureau on completion of their education or on demobilization from the army. We did not have enough information to classify workers as simply 'competitive' or 'assigned' if they obtained their job through the recommendations of friends or relatives or by transfer and thus dropped these cases from our sample.

We presume that assigned jobs in state-owned enterprises comprise the least liberalized sector of the labor market, while jobs found competitively in joint venture enterprises comprise the most liberalized channel. The results of this analysis are shown in Table 4. 
Table 4

Oaxaca and Neumark Decompositions by Enterprise Ownership And the Job Search Channel ${ }^{1}$

\begin{tabular}{|c|c|c|c|c|c|c|}
\hline & \multicolumn{2}{|c|}{ State Enterprise } & \multicolumn{2}{|c|}{$\begin{array}{c}\text { Collective } \\
\text { Enterprise }\end{array}$} & \multicolumn{2}{|c|}{ Joint Enterprise } \\
\hline & Assign & Compete & Assign & Compete & Assign & Compete \\
\hline \multicolumn{7}{|l|}{ Wage } \\
\hline Average Male Wage & 189.55 & 182.91 & 184.98 & 175.16 & 244.05 & 227.69 \\
\hline Average Female Wage & 171.75 & 166.11 & 153.26 & 150.64 & 180.99 & 212.02 \\
\hline Wage Ratio (W/M) & 0.906 & 0.908 & 0.828 & 0.860 & 0.742 & 0.931 \\
\hline N Male & 625 & 388 & 314 & 248 & 131 & 173 \\
\hline N Female & 239 & 322 & 207 & 316 & 97 & 202 \\
\hline \multicolumn{7}{|l|}{$\begin{array}{l}\text { Percent Unexplained } \\
\text { Wage Differential }\end{array}$} \\
\hline Oaxaca $^{2}$ & 34.54 & -20.99 & 45.33 & 43.31 & 42.09 & 51.70 \\
\hline Neumark & 28.22 & -20.01 & 38.08 & 50.92 & 27.91 & 60.90 \\
\hline
\end{tabular}

${ }^{1}$ Estimates calculated from regressions controlling for educational level, job-contract category, industry type, type of wage, family size, party membership, job tenure, experience, and province.

${ }^{2}$ The Oaxaca decompositions were performed using the male wage structure as the reference, or 'no-discrimination' wage structure.

Table 4 shows the clearest evidence of liberalization helping women in the labor market. For women in competitively-obtained state-sector jobs, the unexplained gap even becomes negative. $^{17}$

Competitive positions within joint venture enterprises are arguably the most liberalized segment of the labor market in our data. Regardless of the percentage of the wage gap unexplained by productive characteristics, the actual female-male wage gap, at less than seven percent, is the smallest we found, revealing a high level of earnings equality between male and female workers. Even though the unexplained portion of the

17 In a Oaxaca or Neumark decomposition, a negative unexplained wage gap means that women receive, on average, a wage premium over men, unaccounted for by differences in productive characteristics. 
wage gap is 10 percentage points higher by the Oaxaca method for those who found their jobs competitively than those assigned, and even more by the Neumark method, the discriminatory wage gap is negligible in yuan terms. ${ }^{18}$ Notably, the wage ratio for competitive, joint venture enterprise jobs is higher than the wage ratio for state-owned enterprise jobs. This result weakens the argument that the state acts as 'the great equalizer' or protector of women in ways that competitive firms cannot match.

\section{The Effects of Wage Structure}

Suppose that the relative standing of women were the same across state, collective and joint venture enterprises, after controlling for observed characteristics. That is, the mean woman's wage ranks at, say, the $30^{\text {th }}$ percentile of the men's residual wage distribution. Suppose, however, that overall inequality of men's earnings is larger in joint ventures - the variance of the residual wage distribution is larger in joint ventures. Oaxaca and Neumark decompositions performed in this situation will show a larger unexplained gender wage gap for joint ventures compared to state enterprises, even though discrimination — defined as moving women down the male residual wage distribution - is no worse in joint ventures than state enterprises. Yet standard measures of discrimination show a difference, as the wider dispersal of wages in joint ventures imposes a larger penalty on women for a given deficit on the male residual wage distribution. We now turn to an examination of how such differences in wage structure may affect our findings.

18 The average wage gap is 63 yuan for assigned jobs in joint enterprises and 16 yuan for competitive jobs. Using the lowest estimate of the discriminatory portion in assigned jobs yields a discriminatory wage gap of 18 yuan. Using the higher Neumark estimate of the discriminatory wage gap in competitive jobs yields a discriminatory gap of less than 10 yuan per month. 
We use the Juhn (1991) method described earlier to decompose the difference in gender wage gaps between ownership types into four components: effects of differences in mean observed characteristics; effects of differences in the observed return to these characteristics; effects of differences in women's ranking on the male residual wage distribution, and; differences in overall residual inequality.

Our results are presented using the gender wage gap at state enterprises as the base. We do this to evaluate the putatively more liberalized joint and collective enterprises rela tively to the more restrictive employment practices of the state enterprises. $^{19}$

Results of the Juhn decomposition are presented in Table 5. Our results show that the mean woman's position on the men's residual wage scale contributes little to the relative gender wage gaps. For all types of firms, the mean woman's position on the men's residual wage scale is between around 42 and 47 percent, indicating little difference between the average man's and average woman's wage within ownership types after controlling for observable characteristics, and little difference in the relative placement of women across ownership types. ${ }^{20}$ The column labeled 'Gap' shows the

19 Referring to equation (6), using a common state enterprise base means that interindustry differences in the components of wage structure are weighted using the collective and joint weights (cf. second and fourth terms in (6)), while inter-industry differences in gender-specific factors are weighted using base category, or state enterprise weights (cf. first and third terms in (6)). See Blau and Kahn, (1996), pg. S43.

20 By this measure, the economic standing of Chinese women in all ownership types compares quite favorably with the relative standing of women in other countries. In the international comparison of Blau and Kahn (1996), women's mean ranking in the male residual distribution ranged from a low of 18.5 percent in Norway to a high of 37.5 percent in Switzerland, far lower than our findings for China (Blau and Kahn, 1996, Table 5). 
contribution of the mean women's placement on the men's residual distribution to be negligible, less than two percent.

Table 5

Juhn Decompositions of the Relative Gender Wage

Gap Between State Enterprises and Other

Ownership Types

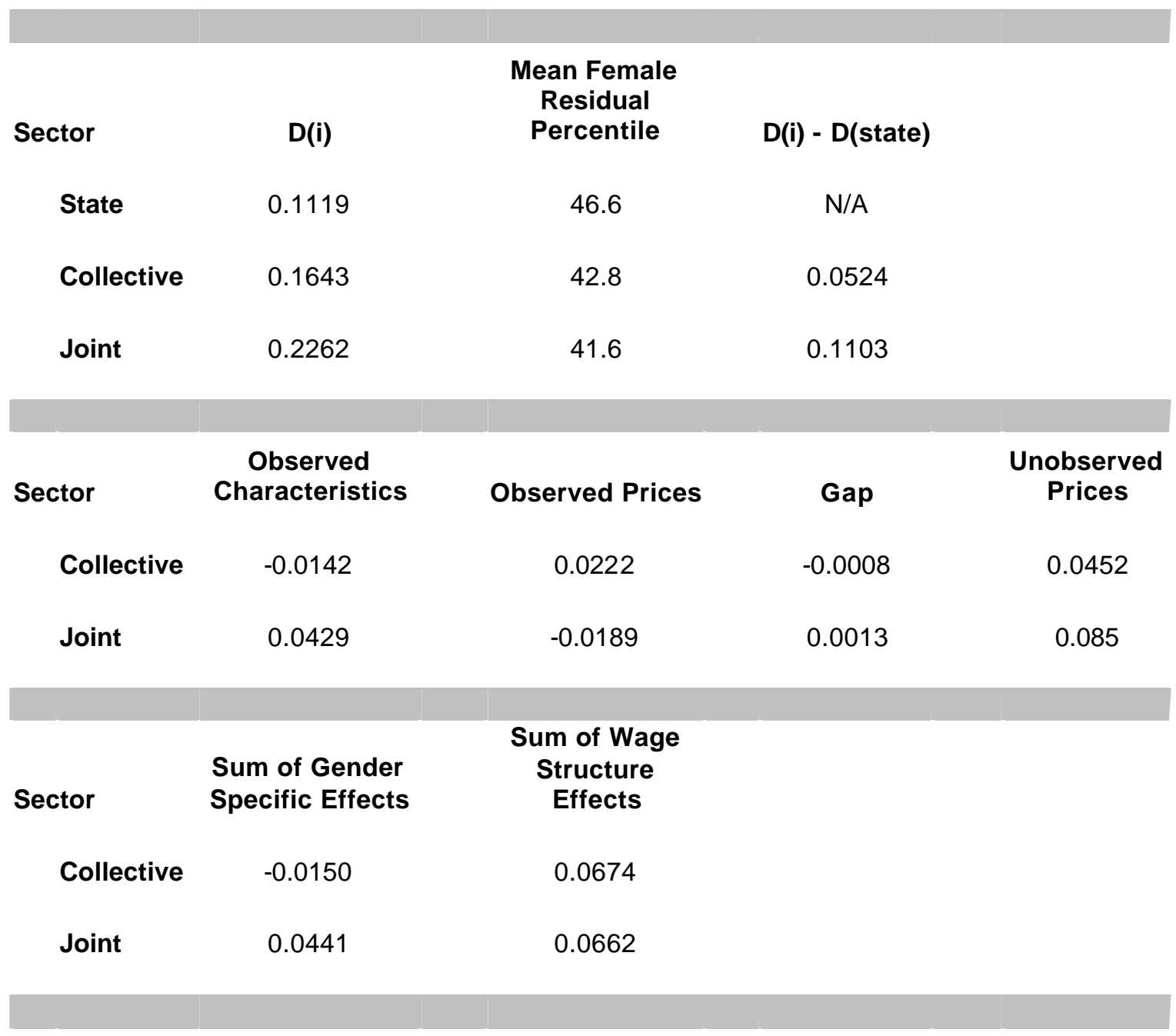

The column labeled 'Unobserved Prices' indicates that a higher level of residual wage dispersion in both collective and joint enterprises accounts substantially for the 


\section{William Davidson Institute Working Paper 460}

larger gender wage gap in these enterprises than in state enterprises. In other words, higher residual wage inequality in collective and joint enterprises imposes a larger wage penalty on women for either shortfalls in mean human capital characteristics or wage discrimination, compared to state enterprises. Residual wage inequality accounts for 86 percent of the relative gender pay gap between collective and state enterprises, and 77 percent of the relative gap between joint venture and state enterprises.

Observed characteristics have differential effects on the relative wage gap at collective and joint enterprises. This figure is positive for joint enterprises, indicating that the women in these enterprises have favorable relative levels of measured human capital characteristics. Women in collective enterprises have somewhat less favorable levels of observable characteristics relative to women in state enterprises.

The effect of observed prices is positive for collective enterprises, meaning that the male returns to the observed characteristics increases the gender wage gap in collective enterprises relative to state enterprises. The effect of observed prices is negative for joint enterprises, indicating that observed prices tend to mitigate the relative gender wage gap between state enterprises and joint venture enterprises.

The final panel of Table 5 aggregates gender specific effects (Observed Characteristics plus Gap effects) and wage structure effects (Observed Prices plus Unobserved Prices). The positive gender-specific effects for women working in joint enterprises reflect their favorable levels of human capital characteristics compared to women in state enterprises. Conversely, women working in collective enterprises have somewhat less favorable levels of human capital characteristics relative to state enterprise 
women. However, this effect is swamped by the large and opposite-signed wage structure effects.

The positive wage structure effects for both collective and joint enterprises indicate that the higher degree of overall wage inequality in these enterprises significantly increases their gender wage gaps relative to state enterprises. For collective enterprises, this wage inequality is more than sufficient to account for the higher wage gap is such enterprises. For joint enterprises, wage inequality accounts for around 60 percent of the larger gender wage gaps relative to state enterprises.

The results of the Juhn decompositions indicate the need to take wage structure issues into account in evaluating the effects of economic liberalization on the economic status of women. After controlling for observable characteristics, we find little difference across industry types in the average woman's placement on the men's residual wage distribution. However, the wage penalty to women from even this small disadvantage is relatively large in both collective and joint enterprises, as the residual wage inequality in both these ownership types is quite large relative to state enterprises.

\section{Conclusion}

We set out to analyze whether the economic reform process in China has worked to women's relative advantage or disadvantage. We focus on one observable aspect of women's economic status - their earnings relative to men's. Working with cross-section data we can not directly observe changes in women's relative earnings over the course of the reforms but we are able exploit sectoral variation in the degree of market liberalization to infer the effects of the reforms on those earnings. 


\section{William Davidson Institute Working Paper 460}

We find wage gaps are largest in the most liberalized sector, that is, the joint venture sector, smaller in the collective sector, and smallest in the least liberalized sector, the state sector. The proportion of the gap left unexplained by differences in observable characteristics (i.e., the proportion often attributed to discrimination) is largest in the joint venture sector and smallest in the state-owned sector. It thus seems, at first glance, that labor market liberalization in China does not work to women's advantage but rather to their disadvantage.

However, we have to emphasize several additional findings. First, the decline in women's pay relative to men's is offset in one sense by an absolute increase in wages. Both women and men in the more liberalized joint venture sector earn more than their counterparts in the state and collective sectors. Second, when we consider where the median woman's earnings fall on the men's income distribution we find that women's relative standing is highest in the joint venture sector. Third, when we proxy the degree of liberalization in the labor market by identifying two groups within our sample- those assigned to their jobs and those who found their employment through the market placewe find "the assigned" group has wider gender pay gaps and that a greater proportion of these gaps is attributable to discrimination. In this regard, liberalization seems to work to women's advantage.

Furthermore, when we take the differences in wage structure into account, it becomes clear that much of the larger gender wage gaps in the joint venture and collective sectors can be explained by the greater degree of wage inequality in those sectors. There is very little difference, by sector, in the mean female percentile ranking on the male residual wage scale, that is, the mean female percentile after controlling for 


\section{William Davidson Institute Working Paper 460}

observable characteristics (the mean percentiles range from 41.6 in the joint venture sector to 46.6 in the state sector). These rankings are extraordinarily high in international comparison and support Meng's contention that programs promoting gender equity in the socialist period were both effective and durable. Although we began our investigation with the idea that wage decentralization and reduced levels of government involvement in Chinese labor markets might lead to a reemergence of discrimination against women, our analysis of the relationship between the degree of market liberalization and the size and composition of the gender wage gaps lends no support to this hypothesis. 
William Davidson Institute Working Paper 460

\section{References}

Abowd, John, Francis Kramarz, and David Margolis. 1999. "High Wage Workers and High Wage Firms" Econometrica, Vol 67, No. 2, pp. 251-333.

Arnold, Julean. 1926. China: A Commercial and Industrial Handbook. Department of Commerce, Bureau of Foreign and Domestic Commerce. Washington: Government Printing House.

Becker, Gary. The Economics of Discrimination, 2d ed. (Chicago, University of Chicago Press) 1971.

Blau, Francine, Ferber, Marianne, and Winkler, Anne, The Economics of Women, Men, and Work, 3rd ed. (Upper Saddle River, NJ, Prentice Hall), 1998.

Blau, Francine and Lawrence Kahn. 1996. "Wage Structure and Gender Earnings Differentials: an International Comparison.” Economica, Volume 63, pp. S29S62.

Blinder, Alan S. 1973. "Wage Discrimination: Reduced Form and Structural Estimates," Journal of Human Resources. Volume 18, No. 4. pp. 436-455.

Brainerd, Elizabeth. 1998. "Winners and Losers in Russia's Economic Transition" American Economic Review. Volume 88. No.5. pp.1094-1116.

Brainerd, Elizabeth. 1997. "Women in Transition: Changes in Gender Wage Differentials in Eastern Europe and the Former Soviet Union" Luxembourg Income Study Working Paper No. 171.

Bronars, Stephen, and Famulari, Melissa. 1997. "Wage, Tenure, and Wage Growth Variation Within and Across Establishments" Journal of Labor Economics. Volume 15, No. 2. pp.285-318.

Chan, Anita, Madsen, Richard, and Unger, Jonathan. 1992. Chen Village Under Mao and Deng. Expanded and Updated Edition. (University of California Press: Berkeley.)

Chen, Gang et al. 1999. Zhongguo dazhong chengshi laodongli shichang gongzi jiawei (Market Wages of Labor in China's Large and Medium Cities). Beijing: Laodong he shehui baozhang chubanshe.

Chen, Jian and Fleisher, Belton. 1996. "Regional Income Inequality and Economic Growth in China," Journal of Comparative Economics, Vol. 22. pp.141-164.

Child, John. 1994. Management in China During the Age of Reform. (Cambridge: Cambridge University Press.) 
Croll, Elisabeth. 1995. Changing Identities of Chinese Women: Rhetoric, Experience, and Self-Perception in Twentieth-Century China. (Hong Kong University Press, Zed Books: London and New Jersey.)

Croll, Elisabeth. 1997. "Gender, Inequality, and Feminism During the First Decades of Reform" paper revised after presentation at the conference "Gender, Households, and the Boundaries of Work in China" at the University of North Carolina at Chapel Hill, October 25-27, 1966.

Fleisher, Belton and Chen, Jian. 1997. "The Coast-Noncoast Income Gap, Productivity, and Regional Economic Policy in China," Journal of Comparative Economics. Vol. 25. pp.220-236.

Gustaffson, Bjorn and Li, Shi. 1998. "Inequality in China at the End of the 1980s: Locational Aspects and Household Chararcteristics," Asian Economic Journal. Vol. 12, No. 1. pp 35-62.

Honig, Emily. 1986. Sisters and Strangers: Women in the Shanghai Cotton Mills, 19191949. Stanford: Stanford University Press.

Jefferson, Gary H and Rawski, Thomas G. 1994. "Enterprise Reform in Chinese Industry," Journal of Economic Perspectives. Vol. 8 (2), pp. 47-70.

Juhn, Chinhui, Kevin Murphy, and Brooks Pierce. 1991. "Accounting for the Slowdown in Black-White Wage Convergence," in Marvin H. Kosters edited Workers and Their Wages: Changing Patterns in the United States. Washington: The AEI Press.

Khan, Azizur Rahman. 1996. "The Impact of Recent Macroeconomic and Sectoral Changes on the Poor and Women in China," ILO Regional Office for Asia and the Pacific, on the Internet at http://www.ilo.org/public/english/region/asro/bangkok/paper/pov all.htm.

Lee, Jongchul. 2000. "Changes in the source of China's Regional Inequality," China Economic Review. Vol.11. Issue 3. pp.232-45.

Lee, Lily Xiao Hong. 1994. The Virtue of Yin: Studies on Chinese Women. Wild Peony: Canberra.

Li, Shi and Gustafsson, Bjorn. 1999. "Zhongguo chengzhen zhigong shuru do xinbie chayi fenxi” (An Analysis of Gender Differences in Urban Workers' Income) in Zhao Ren Wei et al (ed.) Zhongguo zhumin shuru fenpei zai yanjiu: jingji gaige he fazhan zhong de shouru fenpei (Further Research on the Distribution of Chinese Household Income: the Distribution Of Income During Economic Reform and Development). China Finance and Economics Publishing House: Beijing. pp.556-593. 
Liu, Pak-Wai, Meng, Xin, and Zhang, Junsen. 2000. "The Impact of Economic Reform on Gender Wage Differentials and Discrimination in China" Journal of Population Economics. May. Volume 13(2) pp.331-52.

Loscocco, Karyn and Bose, Christine. 1998. "Gender and Job Satisfaction in Urban China: The Early Post-Mao Period” Social Science Quarterly. Volume 79. No.1, March. pp.91-109.

Maurer-Fazio, Margaret, Rawski, Thomas, and Zhang, Wei. 1999. "Inequality in the Rewards for Holding Up Half the Sky: Gender Wage Gaps in China's Urban Labour Market, 1988-1994" The China Journal No. 41, January. pp.55-88.

Meng, Xin. 2000. “Institutions and Culture: Women's Economic Position in Mainland China and Taiwan." Manuscript, Department of Economics, Research School of Pacific and Asian Studies, Australian National University.

Meng, Xin and Kidd, Michael. 1997. "The Gender-Wage Gap in Chinese State Enterprise Sector: Labor Market Reform and the Roles of Institutional Change” Unpublished manuscript, University of Aberdeen.

Neumark, David. 1988. "Employers' Discriminatory Behavior and the Estimation of Wage Discrimination” The Journal of Human Resources. Volume 23, No.3. pp.279-295.

Oaxaca, Ronald. 1973. "Male-Female Wage Differentials in Urban Labor Markets," International Economic Review, Volume 14, No. 3, pp. 693-709.

Rawski, Thomas G. 1989. Economic Growth in Prewar China. Berkeley: University of California Press.

Rawski, Thomas G. 1994. "Chinese Industrial Reform: Accomplishments, Prospects, and Implications,” American Economic Review. Volume 84. No.2. May. pp. 271-275.

Rawski, Thomas G. 2002. "Recent Developments in China's Labor Economy," Manuscript, University of Pittsburgh, Department of Economics.

Zhai, Zhenhua. 1992. Red Flower of China. Soho Press: New York.

ZTN. 1997. Zhongguo Tongji Nianjian 1997. (Statistical Yearbook of China 1997.) China Statistical Publishing House: Beijing

ZTN. 2000. Zhongguo Tongji Nianjian 2000. (Statistical Yearbook of China 2000.) China Statistical Publishing House: Beijing 
William Davidson Institute Working Paper 460

Zveglich, Joseph, van der Meulen Rodgers, Yana, and Rodgers, William. 1997. Industrial and Labor Relations Review. Volume 50, No.4. pp.594-609. 
William Davidson Institute Working Paper 460

\section{Table A1 \\ Descriptive Statistics}

\begin{tabular}{|c|c|c|c|c|c|c|}
\hline \multirow[b]{2}{*}{ Variable } & \multicolumn{2}{|c|}{ State Enterprises } & \multicolumn{2}{|c|}{ Collective Enterprises } & \multicolumn{2}{|c|}{ Joint Enterprises } \\
\hline & Men & Women & Men & Women & Men & Women \\
\hline \multicolumn{7}{|l|}{ Education } \\
\hline \multicolumn{7}{|l|}{ Tears of schooling } \\
\hline 3 Years Primary Education & 0.018 & 0.007 & 0.012 & 0.008 & 0.006 & 0.007 \\
\hline 6 Years Primary Education & 0.052 & 0.021 & 0.063 & 0.026 & 0.033 & 0.023 \\
\hline Junior/Middle School & 0.238 & 0.259 & 0.299 & 0.290 & 0.224 & 0.244 \\
\hline Junior Technical School & 0.050 & 0.038 & 0.025 & 0.039 & 0.022 & 0.030 \\
\hline Senior Middle School & 0.253 & 0.342 & 0.251 & 0.363 & 0.287 & 0.377 \\
\hline Vocational Senior Middle School & 0.018 & 0.036 & 0.027 & 0.044 & 0.041 & 0.084 \\
\hline $\begin{array}{l}\text { TV College, Night College, Correspondence } \\
\text { School }\end{array}$ & 0.075 & 0.066 & 0.081 & 0.049 & 0.097 & 0.047 \\
\hline Specialized High School & 0.120 & 0.120 & 0.116 & 0.097 & 0.097 & 0.079 \\
\hline Specialized College & 0.098 & 0.071 & 0.081 & 0.058 & 0.090 & 0.068 \\
\hline University Graduate & 0.076 & 0.038 & 0.045 & 0.027 & 0.090 & 0.038 \\
\hline Post-Graduate Student & 0.002 & 0.002 & 0.000 & 0.000 & 0.011 & 0.003 \\
\hline \multicolumn{7}{|l|}{ Wage Grade System } \\
\hline Worker & 0.606 & 0.698 & 0.646 & 0.721 & 0.562 & 0.656 \\
\hline Cadre & 0.354 & 0.271 & 0.318 & 0.232 & 0.275 & 0.182 \\
\hline No Wage Grade System & 0.041 & 0.031 & 0.036 & 0.047 & 0.163 & 0.162 \\
\hline \multicolumn{7}{|l|}{ Wage Type } \\
\hline Hourly Wage & 0.220 & 0.270 & 0.203 & 0.221 & 0.203 & 0.229 \\
\hline Piece Rate & 0.058 & 0.047 & 0.080 & 0.086 & 0.084 & 0.103 \\
\hline Fixed or Permanent Wage & 0.646 & 0.600 & 0.629 & 0.611 & 0.595 & 0.583 \\
\hline Floating Wage & 0.076 & 0.082 & 0.087 & 0.082 & 0.117 & 0.086 \\
\hline \multicolumn{7}{|l|}{ Party Membership } \\
\hline Party Member & 0.161 & 0.078 & 0.151 & 0.082 & 0.095 & 0.049 \\
\hline \multicolumn{7}{|l|}{ Industry } \\
\hline Machinery & 0.262 & 0.200 & 0.172 & 0.156 & 0.178 & 0.122 \\
\hline Chemical & 0.147 & 0.115 & 0.175 & 0.128 & 0.135 & 0.110 \\
\hline Textile & 0.067 & 0.087 & 0.094 & 0.123 & 0.160 & 0.211 \\
\hline Electrical & 0.087 & 0.101 & 0.045 & 0.052 & 0.067 & 0.140 \\
\hline Retailing & 0.085 & 0.145 & 0.078 & 0.099 & 0.051 & 0.070 \\
\hline Paper & 0.035 & 0.029 & 0.031 & 0.077 & 0.040 & 0.031 \\
\hline Metal Working & 0.038 & 0.030 & 0.019 & 0.012 & 0.011 & 0.026 \\
\hline Construction & 0.084 & 0.055 & 0.081 & 0.068 & 0.079 & 0.033 \\
\hline Clothing & 0.017 & 0.024 & 0.059 & 0.077 & 0.029 & 0.035 \\
\hline Furniture & 0.008 & 0.016 & 0.018 & 0.022 & 0.025 & 0.038 \\
\hline Excavation & 0.011 & 0.005 & 0.033 & 0.011 & 0.000 & 0.000 \\
\hline Transportation & 0.032 & 0.028 & 0.057 & 0.051 & 0.024 & 0.014 \\
\hline Food & 0.094 & 0.124 & 0.103 & 0.094 & 0.129 & 0.106 \\
\hline Service & 0.011 & 0.022 & 0.019 & 0.014 & 0.073 & 0.063 \\
\hline Energy & 0.019 & 0.017 & 0.018 & 0.015 & 0.000 & 0.000 \\
\hline Other & 0.005 & 0.003 & 0.000 & 0.000 & 0.000 & 0.000 \\
\hline \multicolumn{7}{|l|}{ Family } \\
\hline Age of Worker & 36.886 & 33.103 & 36.222 & 32.843 & 32.746 & 29.340 \\
\hline Family Size & 3.912 & 3.803 & 3.900 & 3.615 & 3.887 & 3.970 \\
\hline Family Members Under 15 & 0.672 & 0.691 & 0.671 & 0.665 & 0.605 & 0.623 \\
\hline
\end{tabular}


William Davidson Institute Working Paper 460

\section{Table A1}

Descriptive Statistics, continued

\begin{tabular}{|l|c|c|c|c|c|c|c|}
\cline { 2 - 7 } \multicolumn{2}{c|}{} & \multicolumn{2}{l|}{ State Enterprises } & Collective Enterprises & \multicolumn{2}{c|}{ Joint Enterprises } \\
\hline Variable & Men & Women & Men & Women & \multicolumn{2}{c|}{ Men } & Women \\
\hline Tenure and Experience & & & & & & \\
\hline Total Years Worked & 17.750 & 14.230 & 17.109 & 14.002 & 13.533 & 10.673 \\
\hline Total Years Squared & 429.483 & 273.508 & 397.818 & 262.745 & 292.256 & 179.442 \\
\hline Years at Current Enterprise & 13.207 & 10.786 & 12.625 & 10.714 & 7.492 & 7.115 \\
\hline Years at Enterprise Squared & 263.281 & 169.494 & 243.215 & 163.200 & 117.371 & 94.850 \\
\hline Province & & & & & & \\
\hline Shanxi & 0.138 & 0.149 & 0.193 & 0.226 & 0.071 & 0.068 \\
\hline Hebei & 0.063 & 0.053 & 0.067 & 0.058 & 0.052 & 0.045 \\
\hline Jilin & 0.081 & 0.116 & 0.106 & 0.126 & 0.071 & 0.108 \\
\hline Jiangsu & 0.075 & 0.063 & 0.065 & 0.072 & 0.124 & 0.133 \\
\hline Anhui & 0.041 & 0.020 & 0.018 & 0.014 & 0.029 & 0.002 \\
\hline Shandong & 0.037 & 0.040 & 0.066 & 0.075 & 0.244 & 0.300 \\
\hline Fujian & 0.055 & 0.057 & 0.045 & 0.044 & 0.083 & 0.086 \\
\hline Hunan & 0.035 & 0.052 & 0.070 & 0.071 & 0.035 & 0.019 \\
\hline Henan & 0.143 & 0.139 & 0.075 & 0.089 & 0.067 & 0.045 \\
\hline Guangdong & 0.075 & 0.063 & 0.034 & 0.024 & 0.168 & 0.120 \\
\hline Hainan & 0.081 & 0.070 & 0.068 & 0.028 & 0.056 & 0.073 \\
\hline Sichuan & 0.176 & 0.178 & 0.193 & 0.174 & 0.000 & 0.000 \\
\hline Wage & & & & & & \\
\hline Ln Wage & 5.250 & 5.138 & 5.203 & 5.039 & 5.515 & 5.289 \\
\hline Yuan per month & 190.63 & 170.36 & 181.73 & 154.34 & 248.33 & 198.06 \\
\hline Number of Observations & & & & & & 573 \\
\hline
\end{tabular}




\section{William Davidson Institute Working Paper 460 \\ Table A2}

(Log) Monthly Income Regressions: State-Owned Enterprises

\begin{tabular}{|c|c|c|c|c|c|c|c|c|c|}
\hline \multirow[b]{3}{*}{ Variable } & \multicolumn{3}{|c|}{ Pooled } & \multicolumn{3}{|c|}{ Men's } & \multicolumn{3}{|c|}{ Women's } \\
\hline & Parameter & Standard & & Parameter & Standard & & Parameter & Standard & \\
\hline & Estimate & Error & $\operatorname{Pr}>|t|$ & Estimate & Error & $\operatorname{Pr}>|t|$ & Estimate & Error & $\operatorname{Pr}>|t|$ \\
\hline Intercept & 4.827 & 0.044 & $<.0001$ & 4.818 & 0.060 & $<.0001$ & 4.813 & 0.065 & $<.0001$ \\
\hline 3 years primary & -0.008 & 0.052 & 0.877 & -0.036 & 0.062 & 0.557 & 0.050 & 0.106 & 0.639 \\
\hline 6 years primary & 0.011 & 0.032 & 0.739 & 0.028 & 0.040 & 0.481 & -0.002 & 0.061 & 0.969 \\
\hline Junior Technical School & 0.041 & 0.031 & 0.188 & 0.041 & 0.041 & 0.315 & 0.040 & 0.049 & 0.415 \\
\hline Senior Middle School & 0.014 & 0.017 & 0.388 & 0.016 & 0.024 & 0.500 & 0.012 & 0.023 & 0.617 \\
\hline Vocational Senior Sch & -0.012 & 0.040 & 0.758 & 0.095 & 0.064 & 0.136 & -0.098 & 0.050 & 0.047 \\
\hline TV/Night College & 0.078 & 0.026 & 0.003 & 0.091 & 0.035 & 0.010 & 0.055 & 0.039 & 0.154 \\
\hline Specialized High Sch & 0.036 & 0.022 & 0.110 & 0.071 & 0.030 & 0.019 & -0.026 & 0.032 & 0.427 \\
\hline Specialized College & 0.107 & 0.026 & $<.0001$ & 0.126 & 0.034 & 0.000 & 0.070 & 0.039 & 0.075 \\
\hline University Graduate & 0.181 & 0.030 & $<.0001$ & 0.213 & 0.039 & $<.0001$ & 0.121 & 0.050 & 0.016 \\
\hline Post-Graduate Studies & 0.133 & 0.140 & 0.342 & 0.040 & 0.193 & 0.835 & 0.174 & 0.201 & 0.386 \\
\hline Cadre & 0.034 & 0.017 & 0.044 & 0.010 & 0.023 & 0.679 & 0.071 & 0.024 & 0.003 \\
\hline Not Wage Graded & -0.066 & 0.033 & 0.044 & -0.044 & 0.042 & 0.302 & -0.125 & 0.051 & 0.015 \\
\hline Piece Rate & 0.070 & 0.029 & 0.014 & 0.099 & 0.039 & 0.010 & 0.023 & 0.043 & 0.597 \\
\hline Fixed Wage & -0.006 & 0.015 & 0.689 & -0.008 & 0.021 & 0.689 & -0.006 & 0.020 & 0.756 \\
\hline Floating Wage & -0.010 & 0.025 & 0.687 & -0.009 & 0.035 & 0.804 & -0.019 & 0.036 & 0.597 \\
\hline Party Member & 0.066 & 0.019 & 0.001 & 0.066 & 0.024 & 0.007 & 0.054 & 0.034 & 0.111 \\
\hline Machinery & 0.091 & 0.024 & 0.000 & 0.123 & 0.033 & 0.000 & 0.042 & 0.033 & 0.207 \\
\hline Chemical & 0.107 & 0.025 & $<.0001$ & 0.130 & 0.036 & 0.000 & 0.075 & 0.036 & 0.040 \\
\hline Textiles & 0.045 & 0.030 & 0.143 & 0.046 & 0.044 & 0.295 & 0.040 & 0.041 & 0.333 \\
\hline Electronic & 0.004 & 0.028 & 0.886 & 0.025 & 0.040 & 0.531 & -0.017 & 0.037 & 0.640 \\
\hline Retailing & 0.018 & 0.027 & 0.501 & 0.068 & 0.040 & 0.090 & -0.027 & 0.035 & 0.452 \\
\hline Paper & -0.056 & 0.039 & 0.151 & -0.077 & 0.053 & 0.146 & 0.011 & 0.058 & 0.845 \\
\hline Metallurgy & 0.185 & 0.037 & $<.0001$ & 0.197 & 0.050 & $<.0001$ & 0.176 & 0.057 & 0.002 \\
\hline Construction & 0.047 & 0.030 & 0.116 & 0.077 & 0.041 & 0.058 & -0.001 & 0.045 & 0.983 \\
\hline Clothing & -0.041 & 0.047 & 0.385 & 0.012 & 0.069 & 0.863 & -0.072 & 0.062 & 0.244 \\
\hline Furniture & 0.062 & 0.061 & 0.310 & 0.092 & 0.097 & 0.346 & 0.052 & 0.076 & 0.497 \\
\hline Excavation & 0.372 & 0.069 & $<.0001$ & 0.442 & 0.085 & $<.0001$ & 0.107 & 0.128 & 0.406 \\
\hline Transportation & 0.075 & 0.040 & 0.062 & 0.111 & 0.055 & 0.042 & 0.038 & 0.059 & 0.525 \\
\hline Services & -0.050 & 0.053 & 0.344 & 0.064 & 0.085 & 0.450 & -0.145 & 0.065 & 0.025 \\
\hline Energy & 0.278 & 0.050 & $<.0001$ & 0.254 & 0.066 & 0.000 & 0.338 & 0.075 & $<.0001$ \\
\hline Other & -0.358 & 0.097 & 0.000 & -0.204 & 0.123 & 0.096 & -0.687 & 0.165 & $<.0001$ \\
\hline Family Size & -0.002 & 0.005 & 0.732 & -0.005 & 0.006 & 0.417 & 0.004 & 0.007 & 0.600 \\
\hline Fam. Under 15 & -0.004 & 0.010 & 0.650 & -0.001 & 0.013 & 0.910 & -0.012 & 0.015 & 0.407 \\
\hline Total years worked & 0.030 & 0.003 & $<.0001$ & 0.033 & 0.004 & $<.0001$ & 0.026 & 0.006 & $<.0001$ \\
\hline Years worked squared & 0.000 & 0.000 & $<.0001$ & 0.000 & 0.000 & $<.0001$ & 0.000 & 0.000 & 0.035 \\
\hline Years at current firm & 0.004 & 0.003 & 0.212 & 0.001 & 0.004 & 0.749 & 0.009 & 0.005 & 0.077 \\
\hline Years at firm squared & 0.000 & 0.000 & 0.248 & 0.000 & 0.000 & 0.656 & 0.000 & 0.000 & 0.154 \\
\hline Shanxi & -0.170 & 0.029 & $<.0001$ & -0.183 & 0.040 & $<.0001$ & -0.129 & 0.043 & 0.003 \\
\hline Hebei & -0.193 & 0.035 & $<.0001$ & -0.210 & 0.046 & $<.0001$ & -0.143 & 0.052 & 0.006 \\
\hline Jilin & -0.296 & 0.030 & $<.0001$ & -0.288 & 0.042 & $<.0001$ & -0.289 & 0.043 & $<.0001$ \\
\hline Anhui & -0.158 & 0.041 & 0.000 & -0.225 & 0.052 & $<.0001$ & 0.025 & 0.072 & 0.725 \\
\hline Shandong & -0.029 & 0.038 & 0.445 & -0.083 & 0.053 & 0.116 & 0.063 & 0.055 & 0.253 \\
\hline Fujian & 0.135 & 0.036 & 0.000 & 0.111 & 0.048 & 0.022 & 0.193 & 0.052 & 0.000 \\
\hline Hunan & -0.075 & 0.037 & 0.043 & -0.085 & 0.053 & 0.110 & -0.032 & 0.051 & 0.530 \\
\hline Henan & -0.302 & 0.029 & $<.0001$ & -0.303 & 0.038 & $<.0001$ & -0.295 & 0.044 & $<.0001$ \\
\hline Guangdong & 0.410 & 0.034 & $<.0001$ & 0.399 & 0.045 & $<.0001$ & 0.422 & 0.051 & $<.0001$ \\
\hline Hainan & 0.080 & 0.035 & 0.022 & 0.049 & 0.046 & 0.280 & 0.136 & 0.055 & 0.014 \\
\hline Sichuan & -0.118 & 0.028 & $<.0001$ & -0.135 & 0.038 & 0.000 & -0.069 & 0.042 & 0.097 \\
\hline No. of obs. & 2778 & & & 1697 & & & 1076 & & \\
\hline Adj. $R^{2}$ & 0.429 & & & 0.412 & & & 0.501 & & \\
\hline F-stat & 44.500 & & & 24.000 & & & 21.460 & & \\
\hline
\end{tabular}

The base case consists of middle-school educated, hourly-paid, "workers" who are employed in the food industry in

Jiangsu Province and are not Party members. 


\section{William Davidson Institute Working Paper 460}

Table A2, continued

(Log) Monthly Income Regressions: Collectively-Owned Enterprises

\begin{tabular}{|c|c|c|c|c|c|c|c|c|c|}
\hline \multirow[b]{2}{*}{ Variable } & \multirow[b]{2}{*}{$\begin{array}{c}\text { Parameter } \\
\text { Estimate }\end{array}$} & \multicolumn{2}{|l|}{ Pooled } & \multicolumn{3}{|c|}{ Men's } & \multicolumn{3}{|c|}{ Women's } \\
\hline & & $\begin{array}{c}\text { Standard } \\
\text { Error }\end{array}$ & $\operatorname{Pr}>|t|$ & $\begin{array}{c}\text { Parameter } \\
\text { Estimate }\end{array}$ & $\begin{array}{c}\text { Standard } \\
\text { Error }\end{array}$ & $\operatorname{Pr}>|t|$ & $\begin{array}{c}\text { Parameter } \\
\text { Estimate }\end{array}$ & $\begin{array}{c}\text { Standard } \\
\text { Error }\end{array}$ & $\operatorname{Pr}>|t|$ \\
\hline Intercept & 4.679 & 0.056 & $<.0001$ & 4.686 & 0.078 & $<.0001$ & 4.710 & 0.083 & $<.0001$ \\
\hline 3 years primary & -0.019 & 0.074 & 0.795 & 0.014 & 0.097 & 0.888 & -0.065 & 0.113 & 0.565 \\
\hline 6 years primary & -0.014 & 0.036 & 0.698 & -0.016 & 0.046 & 0.720 & -0.011 & 0.065 & 0.861 \\
\hline Junior Technical School & 0.063 & 0.043 & 0.141 & 0.026 & 0.067 & 0.701 & 0.106 & 0.055 & 0.054 \\
\hline Senior Middle School & 0.046 & 0.019 & 0.016 & 0.032 & 0.028 & 0.257 & 0.060 & 0.026 & 0.019 \\
\hline Vocational Senior Sch & 0.055 & 0.042 & 0.194 & -0.035 & 0.068 & 0.608 & 0.133 & 0.054 & 0.013 \\
\hline TV/Night College & 0.144 & 0.032 & $<.0001$ & 0.106 & 0.042 & 0.012 & 0.151 & 0.050 & 0.002 \\
\hline Specialized High Sch & 0.063 & 0.028 & 0.024 & 0.033 & 0.039 & 0.396 & 0.077 & 0.040 & 0.056 \\
\hline Specialized College & 0.106 & 0.033 & 0.001 & 0.064 & 0.043 & 0.143 & 0.146 & 0.050 & 0.004 \\
\hline University Graduate & 0.173 & 0.044 & $<.0001$ & 0.127 & 0.058 & 0.030 & 0.181 & 0.068 & 0.008 \\
\hline Cadre & 0.095 & 0.021 & $<.0001$ & 0.119 & 0.029 & $<.0001$ & 0.084 & 0.031 & 0.007 \\
\hline Not Wage Graded & 0.025 & 0.038 & 0.505 & 0.073 & 0.057 & 0.201 & 0.014 & 0.051 & 0.781 \\
\hline Piece Rate & 0.119 & 0.030 & $<.0001$ & 0.182 & 0.044 & $<.0001$ & 0.016 & 0.042 & 0.699 \\
\hline Fixed Wage & 0.005 & 0.018 & 0.799 & -0.014 & 0.027 & 0.596 & 0.011 & 0.025 & 0.655 \\
\hline Floating Wage & 0.101 & 0.029 & 0.001 & 0.108 & 0.042 & 0.010 & 0.078 & 0.041 & 0.060 \\
\hline Party Member & 0.049 & 0.024 & 0.039 & 0.047 & 0.031 & 0.123 & -0.001 & 0.039 & 0.974 \\
\hline Machinery & 0.067 & 0.031 & 0.030 & 0.100 & 0.044 & 0.025 & -0.002 & 0.044 & 0.961 \\
\hline Chemical & 0.121 & 0.031 & $<.0001$ & 0.140 & 0.042 & 0.001 & 0.053 & 0.047 & 0.256 \\
\hline Textiles & 0.122 & 0.033 & 0.000 & 0.140 & 0.048 & 0.004 & 0.106 & 0.047 & 0.025 \\
\hline Electronic & 0.225 & 0.043 & $<.0001$ & 0.180 & 0.063 & 0.004 & 0.237 & 0.059 & $<.0001$ \\
\hline Retailing & -0.056 & 0.033 & 0.092 & -0.078 & 0.049 & 0.114 & -0.049 & 0.046 & 0.284 \\
\hline Paper & 0.019 & 0.039 & 0.636 & 0.027 & 0.068 & 0.694 & 0.022 & 0.050 & 0.658 \\
\hline Metallurgy & 0.075 & 0.063 & 0.240 & 0.170 & 0.085 & 0.045 & -0.137 & 0.098 & 0.164 \\
\hline Construction & 0.144 & 0.036 & $<.0001$ & 0.134 & 0.050 & 0.008 & 0.128 & 0.052 & 0.014 \\
\hline Clothing & -0.096 & 0.038 & 0.011 & -0.126 & 0.055 & 0.021 & -0.082 & 0.053 & 0.125 \\
\hline Furniture & -0.145 & 0.058 & 0.012 & -0.173 & 0.086 & 0.044 & -0.117 & 0.079 & 0.136 \\
\hline Excavation & 0.189 & 0.053 & 0.000 & 0.177 & 0.066 & 0.007 & 0.115 & 0.097 & 0.235 \\
\hline Transportation & 0.044 & 0.039 & 0.261 & -0.009 & 0.055 & 0.863 & 0.064 & 0.055 & 0.245 \\
\hline Services & -0.015 & 0.065 & 0.815 & 0.015 & 0.089 & 0.868 & -0.085 & 0.096 & 0.375 \\
\hline Energy & 0.113 & 0.065 & 0.080 & 0.073 & 0.090 & 0.418 & 0.121 & 0.094 & 0.198 \\
\hline Family Size & -0.001 & 0.006 & 0.879 & 0.010 & 0.007 & 0.196 & -0.017 & 0.010 & 0.077 \\
\hline Fam. Under 15 & 0.001 & 0.013 & 0.913 & -0.003 & 0.017 & 0.885 & -0.016 & 0.020 & 0.429 \\
\hline Total years worked & 0.021 & 0.004 & $<.0001$ & 0.023 & 0.005 & $<.0001$ & 0.023 & 0.007 & 0.001 \\
\hline Years worked squared & 0.000 & 0.000 & 0.081 & 0.000 & 0.000 & 0.077 & 0.000 & 0.000 & 0.175 \\
\hline Years at current firm & 0.007 & 0.004 & 0.067 & 0.007 & 0.005 & 0.197 & 0.014 & 0.007 & 0.027 \\
\hline Years at firm squared & 0.000 & 0.000 & 0.320 & 0.000 & 0.000 & 0.414 & 0.000 & 0.000 & 0.103 \\
\hline Shanxi & -0.119 & 0.035 & 0.001 & -0.140 & 0.051 & 0.007 & -0.114 & 0.047 & 0.015 \\
\hline Hebei & -0.130 & 0.040 & 0.001 & -0.106 & 0.057 & 0.065 & -0.174 & 0.057 & 0.002 \\
\hline Jilin & -0.172 & 0.036 & $<.0001$ & -0.131 & 0.053 & 0.014 & -0.209 & 0.049 & $<.0001$ \\
\hline Anhui & 0.135 & 0.063 & 0.034 & 0.153 & 0.087 & 0.079 & 0.089 & 0.092 & 0.332 \\
\hline Shandong & 0.135 & 0.041 & 0.001 & 0.110 & 0.059 & 0.065 & 0.165 & 0.056 & 0.003 \\
\hline Fujian & 0.023 & 0.047 & 0.622 & 0.051 & 0.067 & 0.442 & -0.022 & 0.067 & 0.746 \\
\hline Hunan & -0.134 & 0.041 & 0.001 & -0.144 & 0.060 & 0.016 & -0.145 & 0.057 & 0.011 \\
\hline Henan & -0.216 & 0.039 & $<.0001$ & -0.189 & 0.058 & 0.001 & -0.241 & 0.052 & $<.0001$ \\
\hline Guangdong & 0.620 & 0.053 & $<.0001$ & 0.693 & 0.073 & $<.0001$ & 0.506 & 0.080 & $<.0001$ \\
\hline Hainan & 0.164 & 0.047 & 0.001 & 0.093 & 0.062 & 0.131 & 0.291 & 0.077 & 0.000 \\
\hline Sichuan & -0.038 & 0.035 & 0.278 & -0.036 & 0.050 & 0.472 & -0.065 & 0.050 & 0.189 \\
\hline No. of obs. & 2179 & & & 1122 & & & 1048 & & \\
\hline Adj. R2 & 0.414 & & & 0.442 & & & 0.384 & & \\
\hline F-stat & 32.680 & & & 18.490 & & & 13.610 & & \\
\hline
\end{tabular}

The base case consists of middle-school educated, hourly-paid, "workers" who are employed in the food industry in

Jiangsu Province and are not Party members. 


\section{William Davidson Institute Working Paper 460 \\ Table A2, continued}

(Log) Monthly Income Regressions: Joint Venture Enterprises

\begin{tabular}{|c|c|c|c|c|c|c|c|c|c|}
\hline \multirow[b]{2}{*}{ Variable } & \multicolumn{3}{|c|}{ Pooled } & \multicolumn{3}{|c|}{ Men's } & \multicolumn{3}{|c|}{ Women's } \\
\hline & $\begin{array}{l}\text { Parameter } \\
\text { Estimate }\end{array}$ & $\begin{array}{c}\text { Standard } \\
\text { Error }\end{array}$ & $\operatorname{Pr}>|t|$ & $\begin{array}{l}\text { Parameter } \\
\text { Estimate }\end{array}$ & $\begin{array}{c}\text { Standard } \\
\text { Error }\end{array}$ & $\operatorname{Pr}>|t|$ & $\begin{array}{l}\text { Parameter } \\
\text { Estimate }\end{array}$ & $\begin{array}{c}\text { Standard } \\
\text { Error }\end{array}$ & $\operatorname{Pr}>|t|$ \\
\hline Intercept & 5.067 & 0.078 & $<.0001$ & 5.039 & 0.108 & $<.0001$ & 5.176 & 0.113 & $<.0001$ \\
\hline 3 years primary & -0.355 & 0.138 & 0.010 & 0.027 & 0.213 & 0.898 & -0.704 & 0.191 & 0.000 \\
\hline Junior Technical School & -0.058 & 0.079 & 0.461 & 0.024 & 0.122 & 0.842 & -0.152 & 0.098 & 0.121 \\
\hline Senior Middle School & 0.016 & 0.033 & 0.636 & 0.009 & 0.049 & 0.854 & 0.010 & 0.043 & 0.812 \\
\hline Vocational Senior Sch & 0.015 & 0.056 & 0.787 & -0.014 & 0.093 & 0.881 & 0.008 & 0.067 & 0.902 \\
\hline TV/Night College & 0.076 & 0.051 & 0.135 & 0.017 & 0.066 & 0.799 & 0.085 & 0.081 & 0.293 \\
\hline Specialized High Sch & 0.063 & 0.049 & 0.204 & 0.030 & 0.069 & 0.663 & 0.062 & 0.069 & 0.369 \\
\hline Specialized College & 0.093 & 0.051 & 0.071 & 0.038 & 0.071 & 0.590 & 0.103 & 0.075 & 0.172 \\
\hline Post-Graduate Studies & 0.360 & 0.140 & 0.010 & 0.260 & 0.166 & 0.120 & 0.378 & 0.269 & 0.161 \\
\hline Cadre & -0.018 & 0.037 & 0.621 & -0.029 & 0.052 & 0.578 & 0.029 & 0.051 & 0.565 \\
\hline Not Wage Graded & 0.173 & 0.037 & $<.0001$ & 0.098 & 0.053 & 0.065 & 0.200 & 0.051 & $<.0001$ \\
\hline Piece Rate & 0.104 & 0.050 & 0.039 & 0.203 & 0.075 & 0.007 & 0.020 & 0.067 & 0.759 \\
\hline Fixed Wage & -0.006 & 0.031 & 0.856 & 0.033 & 0.045 & 0.469 & -0.033 & 0.043 & 0.438 \\
\hline Floating Wage & 0.114 & 0.047 & 0.016 & 0.165 & 0.067 & 0.013 & 0.031 & 0.065 & 0.638 \\
\hline Party Member & 0.063 & 0.050 & 0.209 & 0.101 & 0.063 & 0.113 & -0.019 & 0.081 & 0.817 \\
\hline Machinery & -0.184 & 0.047 & 0.000 & -0.201 & 0.065 & 0.002 & -0.201 & 0.068 & 0.003 \\
\hline Chemical & -0.162 & 0.054 & 0.003 & -0.050 & 0.075 & 0.512 & -0.291 & 0.076 & 0.000 \\
\hline Textiles & -0.106 & 0.046 & 0.021 & -0.117 & 0.067 & 0.082 & -0.087 & 0.062 & 0.161 \\
\hline Electronic & -0.091 & 0.056 & 0.104 & -0.212 & 0.088 & 0.017 & 0.035 & 0.072 & 0.633 \\
\hline Retailing & -0.163 & 0.059 & 0.006 & -0.086 & 0.089 & 0.334 & -0.224 & 0.078 & 0.004 \\
\hline Metallurgy & -0.019 & 0.107 & 0.856 & -0.203 & 0.182 & 0.267 & 0.122 & 0.130 & 0.346 \\
\hline Construction & -0.111 & 0.068 & 0.099 & -0.185 & 0.086 & 0.032 & 0.067 & 0.115 & 0.559 \\
\hline Clothing & 0.063 & 0.077 & 0.413 & -0.027 & 0.113 & 0.810 & 0.166 & 0.104 & 0.111 \\
\hline Furniture & -0.307 & 0.077 & $<.0001$ & -0.341 & 0.120 & 0.005 & -0.249 & 0.097 & 0.011 \\
\hline Transport & 0.340 & 0.095 & 0.000 & 0.195 & 0.124 & 0.116 & 0.529 & 0.144 & 0.000 \\
\hline Service & 0.026 & 0.059 & 0.657 & 0.054 & 0.082 & 0.512 & -0.023 & 0.081 & 0.774 \\
\hline Family Size & -0.014 & 0.009 & 0.130 & -0.015 & 0.013 & 0.258 & -0.013 & 0.013 & 0.319 \\
\hline Fam. Under 15 & 0.001 & 0.019 & 0.942 & -0.013 & 0.030 & 0.666 & 0.002 & 0.025 & 0.921 \\
\hline Total years worked & 0.031 & 0.006 & $<.0001$ & 0.047 & 0.007 & $<.0001$ & 0.000 & 0.010 & 0.976 \\
\hline Years worked squared & 0.000 & 0.000 & 0.027 & -0.001 & 0.000 & $<.0001$ & 0.000 & 0.000 & 0.181 \\
\hline Years at current firm & -0.003 & 0.006 & 0.562 & -0.016 & 0.008 & 0.054 & 0.023 & 0.009 & 0.011 \\
\hline Years at firm squared & 0.000 & 0.000 & 0.941 & 0.000 & 0.000 & 0.111 & -0.001 & 0.000 & 0.014 \\
\hline Shanxi & 0.025 & 0.059 & 0.673 & -0.003 & 0.085 & 0.976 & 0.027 & 0.083 & 0.740 \\
\hline Hebei & 0.074 & 0.069 & 0.287 & 0.087 & 0.097 & 0.372 & 0.014 & 0.095 & 0.881 \\
\hline Jilin & -0.359 & 0.059 & $<.0001$ & -0.136 & 0.089 & 0.128 & -0.520 & 0.075 & $<.0001$ \\
\hline Anhui & -0.125 & 0.102 & 0.225 & -0.064 & 0.116 & 0.580 & -0.266 & 0.384 & 0.489 \\
\hline Shandong & 0.010 & 0.041 & 0.800 & 0.060 & 0.060 & 0.323 & -0.065 & 0.054 & 0.234 \\
\hline Fujian & 0.205 & 0.056 & 0.000 & 0.285 & 0.081 & 0.000 & 0.123 & 0.074 & 0.096 \\
\hline Hunan & 0.335 & 0.088 & 0.000 & 0.366 & 0.117 & 0.002 & 0.232 & 0.133 & 0.083 \\
\hline Henan & -0.207 & 0.063 & 0.001 & -0.184 & 0.085 & 0.030 & -0.366 & 0.093 & 0.000 \\
\hline Guangdong & 0.788 & 0.048 & $<.0001$ & 0.809 & 0.069 & $<.0001$ & 0.722 & 0.066 & $<.0001$ \\
\hline Hainan & 0.388 & 0.061 & $<.0001$ & 0.475 & 0.089 & $<.0001$ & 0.235 & 0.083 & 0.005 \\
\hline No. of obs. & 1207 & & & 630 & & & 573 & & \\
\hline Adj. R2 & 0.464 & & & 0.490 & & & 0.544 & & \\
\hline F-stat & 24.700 & & & 12.760 & & & 14.330 & & \\
\hline
\end{tabular}

The base case consists of middle-school educated, hourly-paid, "workers" who are employed in the food industry in

Jiangsu Province and are not Party members. 
William Davidson Institute Working Paper 460

Table A3--Parsimonious Model

(Log) Monthly Income Regressions: State-Owned Enterprises

\begin{tabular}{|c|c|c|c|c|c|c|c|c|c|}
\hline \multirow[b]{2}{*}{ Variable } & \multicolumn{3}{|c|}{ Pooled } & \multicolumn{3}{|c|}{ Men's } & \multicolumn{3}{|c|}{ Women's } \\
\hline & $\begin{array}{c}\text { Parameter } \\
\text { Estimate }\end{array}$ & $\begin{array}{c}\text { Standard } \\
\text { Error }\end{array}$ & $\operatorname{Pr}>|t|$ & $\begin{array}{c}\text { Parameter } \\
\text { Estimate }\end{array}$ & $\begin{array}{c}\text { Standard } \\
\text { Error }\end{array}$ & $\operatorname{Pr}>|t|$ & $\begin{array}{c}\text { Parameter } \\
\text { Estimate }\end{array}$ & $\begin{array}{c}\text { Standard } \\
\text { Error }\end{array}$ & $\operatorname{Pr}>|t|$ \\
\hline Intercept & 4.837 & 0.032 & $<.0001$ & 4.847 & 0.043 & $<.0001$ & 4.817 & 0.049 & $<.0001$ \\
\hline 3 years primary & -0.035 & 0.053 & 0.504 & -0.062 & 0.062 & 0.322 & 0.055 & 0.109 & 0.610 \\
\hline 6 years primary & -0.008 & 0.033 & 0.810 & -0.001 & 0.040 & 0.983 & -0.057 & 0.061 & 0.358 \\
\hline Junior Technical School & 0.071 & 0.032 & 0.026 & 0.065 & 0.041 & 0.119 & 0.074 & 0.050 & 0.142 \\
\hline Senior Middle School & 0.019 & 0.017 & 0.262 & 0.018 & 0.024 & 0.457 & 0.022 & 0.023 & 0.342 \\
\hline Vocational Senior Sch & 0.015 & 0.041 & 0.714 & 0.129 & 0.064 & 0.045 & -0.081 & 0.051 & 0.110 \\
\hline TV/Night College & 0.108 & 0.026 & $<.0001$ & 0.094 & 0.034 & 0.006 & 0.121 & 0.038 & 0.002 \\
\hline Specialized High Sch & 0.066 & 0.021 & 0.002 & 0.084 & 0.029 & 0.004 & 0.023 & 0.031 & 0.444 \\
\hline Specialized College & 0.153 & 0.024 & $<.0001$ & 0.140 & 0.031 & $<.0001$ & 0.159 & 0.037 & $<.0001$ \\
\hline University Graduate & 0.239 & 0.028 & $<.0001$ & 0.242 & 0.035 & $<.0001$ & 0.206 & 0.048 & $<.0001$ \\
\hline Post-Graduate Studies & 0.177 & 0.142 & 0.214 & 0.044 & 0.196 & 0.822 & 0.288 & 0.203 & 0.156 \\
\hline Total years worked & 0.030 & 0.003 & $<.0001$ & 0.035 & 0.004 & $<.0001$ & 0.024 & 0.005 & $<.0001$ \\
\hline Years worked squared & 0.000 & 0.000 & $<.0001$ & 0.000 & 0.000 & $<.0001$ & 0.000 & 0.000 & 0.133 \\
\hline Years at current firm & 0.005 & 0.003 & 0.112 & 0.002 & 0.004 & 0.551 & 0.010 & 0.005 & 0.060 \\
\hline Years at firm squared & 0.000 & 0.000 & 0.181 & 0.000 & 0.000 & 0.550 & 0.000 & 0.000 & 0.152 \\
\hline Shanxi & -0.146 & 0.028 & $<.0001$ & -0.134 & 0.037 & 0.000 & -0.157 & 0.041 & 0.000 \\
\hline Hebei & -0.171 & 0.034 & $<.0001$ & -0.195 & 0.044 & $<.0001$ & -0.130 & 0.051 & 0.011 \\
\hline Jilin & -0.272 & 0.030 & $<.0001$ & -0.269 & 0.041 & $<.0001$ & -0.264 & 0.043 & $<.0001$ \\
\hline Anhui & -0.133 & 0.040 & 0.001 & -0.196 & 0.050 & $<.0001$ & 0.035 & 0.071 & 0.625 \\
\hline Shandong & 0.009 & 0.038 & 0.817 & -0.046 & 0.052 & 0.382 & 0.095 & 0.056 & 0.089 \\
\hline Fujian & 0.111 & 0.034 & 0.001 & 0.078 & 0.046 & 0.087 & 0.167 & 0.050 & 0.001 \\
\hline Hunan & -0.041 & 0.037 & 0.268 & -0.043 & 0.053 & 0.411 & -0.008 & 0.051 & 0.869 \\
\hline Henan & -0.291 & 0.028 & $<.0001$ & -0.289 & 0.037 & $<.0001$ & -0.292 & 0.042 & $<.0001$ \\
\hline Guangdong & 0.424 & 0.032 & $<.0001$ & 0.429 & 0.042 & $<.0001$ & 0.415 & 0.049 & $<.0001$ \\
\hline Hainan & 0.090 & 0.032 & 0.004 & 0.036 & 0.041 & 0.382 & 0.187 & 0.048 & $<.0001$ \\
\hline Sichuan & -0.099 & 0.027 & 0.000 & -0.108 & 0.036 & 0.003 & -0.074 & 0.040 & 0.065 \\
\hline No. of obs. & 2778 & & & 1697 & & & 1076 & & \\
\hline Adj. $R^{2}$ & 0.396 & & & 0.364 & & & 0.429 & & \\
\hline F-stat & 86.020 & & & 45.980 & & & 39.320 & & \\
\hline
\end{tabular}

The base case consists of middle-school educated workers in Jiangsu Province. 
William Davidson Institute Working Paper 460

Table A3, continued

(Log) Monthly Income Regressions: Collectively-Owned Enterprises

\begin{tabular}{|c|c|c|c|c|c|c|c|c|}
\hline & Pooled & & & Men's & & & Women's & \\
\hline Parameter & Standard & & Parameter & tandard & & Parameter & Standard & \\
\hline Estimate & Error & $\operatorname{Pr}>|t|$ & Estimate & Error & $\operatorname{Pr}>|t|$ & Estimate & Error & $\operatorname{Pr}>|t|$ \\
\hline 4.826 & 0.040 & $<.0001$ & 4.882 & 0.060 & $<.0001$ & 4.758 & 0.054 & $<.0001$ \\
\hline-0.031 & 0.076 & 0.682 & -0.028 & 0.100 & 0.779 & -0.046 & 0.115 & 0.691 \\
\hline-0.022 & 0.037 & 0.547 & -0.043 & 0.047 & 0.363 & -0.016 & 0.065 & 0.810 \\
\hline 0.064 & 0.044 & 0.142 & 0.025 & 0.070 & 0.726 & 0.125 & 0.056 & 0.025 \\
\hline 0.053 & 0.019 & 0.007 & 0.036 & 0.030 & 0.226 & 0.077 & 0.026 & 0.003 \\
\hline 0.055 & 0.043 & 0.206 & -0.044 & 0.070 & 0.532 & 0.135 & 0.054 & 0.013 \\
\hline 0.173 & 0.032 & $<.0001$ & 0.130 & 0.042 & 0.002 & 0.195 & 0.049 & $<.0001$ \\
\hline 0.121 & 0.026 & $<.0001$ & 0.097 & 0.037 & 0.009 & 0.135 & 0.037 & 0.000 \\
\hline 0.188 & 0.031 & $<.0001$ & 0.137 & 0.043 & 0.001 & 0.236 & 0.045 & $<.0001$ \\
\hline 0.275 & 0.042 & $<.0001$ & 0.234 & 0.055 & $<.0001$ & 0.271 & 0.064 & $<.0001$ \\
\hline 0.021 & 0.004 & $<.0001$ & 0.021 & 0.005 & $<.0001$ & 0.022 & 0.006 & 0.000 \\
\hline 0.000 & 0.000 & 0.175 & 0.000 & 0.000 & 0.222 & 0.000 & 0.000 & 0.213 \\
\hline 0.008 & 0.004 & 0.060 & 0.007 & 0.005 & 0.214 & 0.014 & 0.007 & 0.031 \\
\hline 0.000 & 0.000 & 0.305 & 0.000 & 0.000 & 0.443 & 0.000 & 0.000 & 0.140 \\
\hline-0.195 & 0.032 & $<.0001$ & -0.191 & 0.048 & $<.0001$ & -0.209 & 0.042 & $<.0001$ \\
\hline-0.159 & 0.041 & $<.0001$ & -0.148 & 0.059 & 0.012 & -0.193 & 0.055 & 0.001 \\
\hline-0.241 & 0.035 & $<.0001$ & -0.191 & 0.053 & 0.000 & -0.298 & 0.046 & $<.0001$ \\
\hline 0.046 & 0.064 & 0.470 & 0.084 & 0.089 & 0.344 & -0.021 & 0.091 & 0.816 \\
\hline 0.082 & 0.039 & 0.036 & 0.066 & 0.058 & 0.256 & 0.098 & 0.052 & 0.059 \\
\hline-0.108 & 0.044 & 0.015 & -0.076 & 0.065 & 0.237 & -0.165 & 0.060 & 0.006 \\
\hline-0.205 & 0.039 & $<.0001$ & -0.202 & 0.058 & 0.001 & -0.225 & 0.053 & $<.0001$ \\
\hline-0.290 & 0.038 & $<.0001$ & -0.262 & 0.056 & $<.0001$ & -0.315 & 0.050 & $<.0001$ \\
\hline 0.655 & 0.050 & $<.0001$ & 0.736 & 0.071 & $<.0001$ & 0.539 & 0.074 & $<.0001$ \\
\hline 0.085 & 0.043 & 0.051 & 0.031 & 0.058 & 0.593 & 0.178 & 0.071 & 0.012 \\
\hline-0.104 & 0.033 & 0.002 & -0.079 & 0.049 & 0.105 & -0.151 & 0.044 & 0.001 \\
\hline 2179 & & & 1122 & & & 1048 & & \\
\hline 0.357 & & & 0.348 & & & 0.324 & & \\
\hline 51.350 & & & 30.000 & & & 21.890 & & \\
\hline
\end{tabular}

Variable
Intercept
3 years primary
6 years primary
Junior Technical School
Senior Middle School
Vocational Senior Sch
TV/Night College
Specialized High Sch
Specialized College
University Graduate
Total years worked
Years worked squared
Years at current firm
Years at firm squared
Shanxi
Hebei
Jilin
Anhui
Shandong
Fujian
Hunan
Henan
Guangdong
Hainan
Sichuan
No. of obs.
Adj. R2
F-stat
Sula

The base case consists of middle-school educated workers in Jiangsu Province. 
William Davidson Institute Working Paper 460

Table A3, continued

(Log) Monthly Income Regressions: Joint Venture Enterprises

\begin{tabular}{|c|c|c|c|c|c|c|c|c|c|}
\hline \multirow[b]{2}{*}{ Variable } & \multicolumn{3}{|c|}{ Pooled } & \multicolumn{3}{|c|}{ Men's } & \multicolumn{3}{|c|}{ Women's } \\
\hline & $\begin{array}{c}\text { Parameter } \\
\text { Estimate }\end{array}$ & $\begin{array}{c}\text { Standard } \\
\text { Error }\end{array}$ & $\operatorname{Pr}>|t|$ & $\begin{array}{c}\text { Parameter } \\
\text { Estimate }\end{array}$ & $\begin{array}{c}\text { Standard } \\
\text { Error }\end{array}$ & $\operatorname{Pr}>|t|$ & $\begin{array}{l}\text { Parameter } \\
\text { Estimate }\end{array}$ & $\begin{array}{l}\text { Standard } \\
\text { Error }\end{array}$ & $\operatorname{Pr}>|t|$ \\
\hline Intercept & 5.012 & 0.052 & $<.0001$ & 4.967 & \multicolumn{2}{|c|}{$0.074<.0001$} & 5.091 & 0.073 & $<.0001$ \\
\hline 3 years primary & -0.357 & 0.142 & 0.012 & -0.022 & 0.215 & 0.920 & -0.772 & 0.201 & 0.000 \\
\hline 6 years primary & -0.002 & 0.078 & 0.977 & -0.067 & 0.102 & 0.512 & 0.090 & 0.119 & 0.448 \\
\hline Junior Technical School & -0.064 & 0.080 & 0.430 & 0.072 & 0.121 & 0.553 & -0.192 & 0.103 & 0.062 \\
\hline Senior Middle School & 0.015 & 0.033 & 0.646 & -0.001 & 0.049 & 0.982 & 0.016 & 0.044 & 0.721 \\
\hline Vocational Senior Sch & 0.017 & 0.057 & 0.761 & -0.014 & 0.093 & 0.881 & 0.016 & 0.070 & 0.823 \\
\hline TV/Night College & 0.093 & 0.052 & 0.070 & 0.031 & 0.066 & 0.639 & 0.113 & 0.084 & 0.178 \\
\hline Specialized High Sch & 0.071 & 0.048 & 0.139 & 0.058 & 0.066 & 0.378 & 0.068 & 0.069 & 0.325 \\
\hline Specialized College & 0.115 & 0.051 & 0.023 & 0.059 & 0.068 & 0.385 & 0.132 & 0.075 & 0.078 \\
\hline University Graduate & 0.272 & 0.055 & $<.0001$ & 0.250 & 0.069 & 0.000 & 0.185 & 0.093 & 0.047 \\
\hline Post-Graduate Studies & 0.344 & 0.142 & 0.016 & 0.212 & 0.165 & 0.200 & 0.404 & 0.281 & 0.151 \\
\hline Total years worked & 0.029 & 0.005 & $<.0001$ & 0.051 & \multicolumn{2}{|c|}{$0.007<.0001$} & -0.005 & 0.009 & 0.620 \\
\hline Years worked squared & 0.000 & 0.000 & 0.023 & -0.001 & \multicolumn{2}{|c|}{$0.000<.0001$} & 0.001 & 0.000 & 0.086 \\
\hline Years at current firm & -0.010 & 0.006 & 0.090 & -0.022 & 0.008 & 0.004 & 0.021 & 0.010 & 0.029 \\
\hline Years at firm squared & 0.000 & 0.000 & 0.378 & 0.001 & 0.000 & 0.023 & -0.001 & 0.000 & 0.022 \\
\hline Shanxi & 0.045 & 0.057 & 0.422 & 0.065 & 0.080 & 0.412 & -0.004 & 0.078 & 0.957 \\
\hline Hebei & 0.091 & 0.064 & 0.155 & 0.061 & 0.088 & 0.489 & 0.104 & 0.090 & 0.246 \\
\hline Jilin & -0.368 & 0.053 & $<.0001$ & -0.205 & 0.080 & 0.010 & -0.459 & 0.068 & $<.0001$ \\
\hline Anhui & -0.185 & 0.102 & 0.071 & -0.215 & 0.111 & 0.054 & -0.104 & 0.395 & 0.791 \\
\hline Shandong & -0.003 & 0.041 & 0.942 & 0.045 & 0.060 & 0.455 & -0.067 & 0.055 & 0.221 \\
\hline Fujian & 0.227 & 0.055 & $<.0001$ & 0.294 & 0.079 & 0.000 & 0.172 & 0.073 & 0.019 \\
\hline Hunan & 0.321 & 0.081 & $<.0001$ & 0.453 & \multicolumn{2}{|c|}{$0.103<.0001$} & 0.056 & 0.130 & 0.668 \\
\hline Henan & -0.217 & 0.061 & 0.000 & -0.177 & 0.082 & 0.031 & -0.339 & 0.091 & 0.000 \\
\hline Guangdong & 0.777 & 0.046 & $<.0001$ & 0.785 & \multicolumn{2}{|c|}{$0.064<.0001$} & 0.742 & 0.066 & $<.0001$ \\
\hline Hainan & 0.425 & 0.059 & $<.0001$ & 0.436 & \multicolumn{2}{|c|}{$0.087<.0001$} & 0.376 & 0.078 & $<.0001$ \\
\hline No. of obs. & 1207 & & & 630 & & & 573 & & \\
\hline Adj. R2 & 0.421 & & & 0.419 & & & 0.432 & & \\
\hline F-stat & 37.470 & & & 19.860 & & & 19.140 & & \\
\hline
\end{tabular}

The base case consists of middle-school educated workers in Jiangsu Province. 


\section{DAVIDSON INSTITUTE WORKING PAPER SERIES - Most Recent Papers}

The entire Working Paper Series may be downloaded free of charge at: www.wdi.bus.umich.edu

CURRENT AS 5/1/02

\begin{tabular}{|c|c|c|}
\hline Publication & Authors & Date \\
\hline $\begin{array}{l}\text { No. 460: The Effects of Market Liberalization on the Relative Earnings } \\
\text { of Chinese Women }\end{array}$ & $\begin{array}{l}\text { Margaret Maurer-Fazio and James } \\
\text { Hughes }\end{array}$ & Mar. 2002 \\
\hline $\begin{array}{l}\text { No. 459: The Role of Education in Determining Labor Market } \\
\text { Outcomes in Urban China's Transitional Labor Markets }\end{array}$ & Margaret Maurer-Fazio & Apr. 2002 \\
\hline $\begin{array}{l}\text { No. 458: Real and Monetary Convergence within the European Union } \\
\text { and Between the European Union and Candidate Countries: } \\
\text { A Rolling Cointegration Approach }\end{array}$ & $\begin{array}{l}\text { Josef C. Brada, Ali M. Kutan and } \\
\text { Su Zhou }\end{array}$ & Apr. 2002 \\
\hline No. 457: Credit Ratings as Coordination Mechanisms & $\begin{array}{l}\text { Arnoud W. A. Boot and Todd T. } \\
\text { Milbourn }\end{array}$ & Mar. 2002 \\
\hline $\begin{array}{l}\text { No. 456: Balkan and Mediterranean Candidates for European Union } \\
\text { Membership: The Convergence of their Monetary Policy with that of the } \\
\text { European Central Bank }\end{array}$ & Josef C. Brada and Ali M. Kutan & Apr. 2002 \\
\hline $\begin{array}{l}\text { No. 455: Russian Financial Transition: The Development of Institutions } \\
\text { and Markets for Growth }\end{array}$ & David M. Kemme & Oct. 2001 \\
\hline $\begin{array}{l}\text { No. 454: Does the Market Pay Off? Earnings Inequality and Returns to } \\
\text { Education in Urban China }\end{array}$ & Xiaogang $\mathrm{Wu}$ and $\mathrm{Yu} \mathrm{Xie}$ & Apr. 2002 \\
\hline $\begin{array}{l}\text { No. 453: Entrepreneurs' Access to Private Equity in China: } \\
\text { The Role of Social Capital }\end{array}$ & Bat Batjargal and Mannie M. Liu & Apr. 2002 \\
\hline $\begin{array}{l}\text { No. 452: The Determinants of Privatised Enterprise Performance in } \\
\text { Russia }\end{array}$ & $\begin{array}{l}\text { Alan A. Bevan, Saul Estrin, Boris } \\
\text { Kuznetsov, Mark E. Schaffer, } \\
\text { Manuela Angelucci, Julian } \\
\text { Fennema and Giovanni } \\
\text { Mangiarotti }\end{array}$ & June 2001 \\
\hline $\begin{array}{l}\text { No. 451: Determinants of Financial Distress: What Drives Bankruptcy } \\
\text { in a Transition Economy? The Czech Republic Case }\end{array}$ & Lubomír Lízal & Jan. 2002 \\
\hline No. 450: Corporate Governance and the Global Social Void & Lee A. Tavis & Oct. 2001 \\
\hline $\begin{array}{l}\text { No. 449: Financial Architecture and Economic Performance: } \\
\text { International Evidence }\end{array}$ & Solomon Tadesse & Aug. 2001 \\
\hline $\begin{array}{l}\text { No. 448: Growth Slowdown Under Central Planning: A Model of Poor } \\
\text { Incentives }\end{array}$ & Zuzana Brixiová and Aleš Bulír & Mar. 2002 \\
\hline $\begin{array}{l}\text { No. 447: Disentangling Treatment Effects of Polish Active Labor } \\
\text { Market Policies: Evidence from Matched Samples }\end{array}$ & $\begin{array}{l}\text { Jochen Kluve, Hartmut Lehmann, } \\
\text { and Christoph M. Schmidt }\end{array}$ & Jan. 2002 \\
\hline $\begin{array}{l}\text { No. 446: The Impact of Socialist Imprinting and Search for Knowledge } \\
\text { on Resource Change: An Empirical Study of Firms in Lithuania }\end{array}$ & $\begin{array}{l}\text { Aldas Kriauciunas and Prashant } \\
\text { Kale }\end{array}$ & Mar. 2002 \\
\hline $\begin{array}{l}\text { No. 445: The Costs, Wealth Effects, and Determinants of International } \\
\text { Capital Raising: Evidence from Public Yankee Bonds }\end{array}$ & $\begin{array}{l}\text { Darius P. Miller and John J. } \\
\text { Puthenpurackal }\end{array}$ & Oct. 2001 \\
\hline No. 444: Financial Institutions, Contagious Risks, and Financial Crises & $\begin{array}{l}\text { Haizhou Huang and Chenggang } \\
\mathrm{Xu}\end{array}$ & Nov. 2001 \\
\hline No. 443: Banks as Catalysts for Industrialization & $\begin{array}{l}\text { Marco Da Rin and Thomas } \\
\text { Hellmann }\end{array}$ & Oct. 2001 \\
\hline $\begin{array}{l}\text { No. 442: Bank-Based or Market-Based Financial Systems: Which is } \\
\text { Better? }\end{array}$ & Ross Levine & Feb. 2002 \\
\hline $\begin{array}{l}\text { No. 441: Migration and Regional Adjustment and Asymmetric Shocks } \\
\text { in Transition Economies }\end{array}$ & Jan Fidrmuc & Feb. 2002 \\
\hline $\begin{array}{l}\text { No. 440: Employment and Wages in Enterprises Under Communism } \\
\text { and in Transition: Evidence From Central Europe and Russia }\end{array}$ & $\begin{array}{l}\text { Swati Basu, Saul Estrin, and Jan } \\
\text { Svejnar }\end{array}$ & June 2000 \\
\hline No. 439: Small business in Russia: A Case Study of St. Petersburg & Alessandro Kihlgren & Jan. 2002 \\
\hline $\begin{array}{l}\text { No. 438: Foreign Direct Investment as Technology Transferred: } \\
\text { Some Panel Evidence from the Transition Economies }\end{array}$ & $\begin{array}{l}\text { Nauro F. Campos and Yuko } \\
\text { Kinoshita }\end{array}$ & Jan. 2002 \\
\hline No. 437: Whistleblowing, MNC's and Peace & Terry Morehead Dworkin & Feb. 2002 \\
\hline
\end{tabular}

